\title{
Bending and dynamic analyses of sandwich panels considering the size effect of sandwich core
}

\author{
Ke-peng Qiu, Wei-hong Zhang ${ }^{\mathrm{a}}$, Ji-hong Zhu
}

The Key Laboratory of Contemporary Design \& Integrated Manufacturing Technology, Northwestern Polytechnical University, 710072, Xi’an, Shaanxi, China

Received 21 April 2009, Accepted 5 August 2009

\begin{abstract}
In this paper, the bending and dynamic responses of sandwich panels with the size variation of different sandwich cores and the homogenized cores are analyzed numerically, including the hexagonal and rectangular cores, the square and rhombic cores and the circle and X-shape corrugated cores. In dependence on the ratio of the span dimensions to thickness, the laminate plate theory is also adopted for the static and dynamic analysis of sandwich panels with the homogenized cores. The computational results demonstrate the influencing rule of size variation of unit cells in the sandwich core on the bending and dynamic response of sandwich panels.
\end{abstract}

Key words: Sandwich panel, Bending response, Dynamic analysis, Homogenization method, Size effect

\section{Introduction}

A typical sandwich panel is composed of the upper and lower skins and a lightweight core. Common patterns of sandwich cores, e.g. foam, truss, honeycombs and corrugated cores [1-4] are shown in Fig.1. Different detailed structural forms are involved such as the foam cores with the open or close cells, different truss configurations, honeycomb cores and the corrugated core with different shapes. Moreover, attractive properties like high specific stiffness and strength, high impact energy absorption, sound damping, electromagnetic wave absorption, thermal insulation and non combustibility [5-7] can be obtained. Therefore, sandwich panels are extensively used in the aerospace, building, automobile, package, and shipbuilding industries.

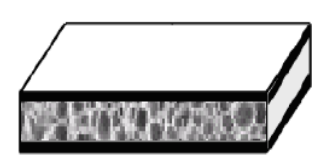

(a) Foam cores

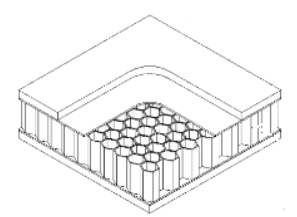

(c) Honeycomb cores

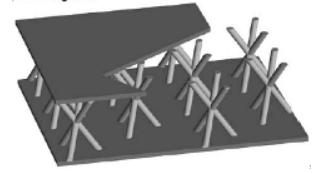

(b) Truss cores

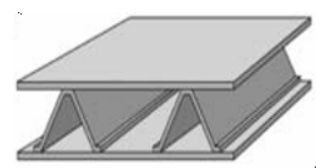

(d) Corrugated cores
Fig. 1. Sandwich panels with the different cores

Most studies on the sandwich panel presently focus on the following two aspects. Firstly, various kinds of methods involved in the homogenization method, the analytical method and the experimental method are pursued to obtain the effective properties of sandwich panels with the different cores. Buannic et al. [8] computed the effective properties of sandwich panel with the corrugated core with the homogenization method and derived the equivalent Kirchhoff-Love and Reissner-Mindlin homogeneous plate. Meraghni et al. [9] developed three approaches of finite element analysis, analytical study and experimental tests to determine the mechanical properties of the honeycomb and tubular cores for sandwich panels. Xu and Qiao [10] applied the multi-pass homogenization technique to solve the equivalent stiffness of the sandwich with the skin effect. Hohe and Becker [11] used a strain energy-based representative volume element procedure for the determination of the effective properties of two-dimensional cellular sandwich cores with arbitrary cell topology and geometry. Xue and Hutchinson [12] proposed a valid constitutive model for quasi-static deformation of three kinds of metallic sandwich cores. Secondly, structural responses of sandwich panels including the bending, impact, vibration and bulking responses are evaluated. Romanoff and Varsta [13] evaluated the bending response of web-core sandwich plates by transforming an originally discrete core into an equivalent homogenous continuum with the effect of thick-face-plates considered. The equivalent stiffness properties of the plate are determined by analytical formulations. Glenn and Hyer [14] developed a theory to predict the outof-plane deflections of sandwich plates. Paik et al. [15] investigated the strength characteristics of aluminum sandwich panels with aluminum honeycomb core. Koissin et al. [16] addressed the elastic response of sandwich panels to local static and dynamic loading. Meo et al. [17] made an experimental investigation and a numerical simulation on the impact damage over a range of sandwich panels. They revealed the load distribution in damaged sandwich structures and studied the failure mechanisms of such a structure in the presence of impact damage. Pokharel and Mahendran [18] investigated local buckling behavior of sandwich panels using experimental and finite element analysis. Frostig and

\footnotetext{
a Corresponding author: zhangwh@nwpu.edu.cn
} 
Thomsen [19] presented free vibration analysis of sandwich panels with a flexible core based on the high-order sandwich panel theory. Chang et al. [20] presented a closed-form solution based on the Mindlin-Reissner plate theory to describe the behavior of corrugated-core sandwich plate bending with various boundary conditions.

The above-presented researchers and many others have carried out plenty of outstanding and in-depth studies on the sandwich panel. However, few attentions are paid on the size effect on the mechanical properties of the few of the sandwich cores. Tekoglu and Onck [21] pointed out that mechanical properties of cellular materials depend strongly on the specimen size to the cell size ratio. The size effect was addressed by Onck et al. [22] for the in-plane elastic constants of hexagonal honeycombs based on the finite element modeling and experimental tests. Recently, Dai and Zhang [23] studied size effects of the 2D basic cell of sandwich beams in a systematic way and demonstrated the importance of size effect theoretically and numerically. Therefore, it's necessary to further explore the size effect of 3D sandwich core in analyzing the mechanical response of sandwich panel. In this paper, by varying the size of the unit cells composing sandwich cores, the bending and dynamic responses of the sandwich panel are evaluated and compared by using the analytical and numerical methods on the basis of homogenization method.

The rest of this paper is organized as follows: in Section 2, the homogenization method and classical laminate plate theory are introduced simply. In Section 3, the bending responses of sandwich panels with the different size honeycomb and corrugated cores are computed numerically. And also, the laminate plate theory and the finite element method are adopted to analyze their bending responses based on the effective sandwich cores predicted by the 3D homogenization method. In Section 4, we also analyze numerically and theoretically the dynamic responses of sandwich panels with the different size honeycomb cores and the homogenized cores. In Section 5, conclusions are drawn and further works are pointed out.

\section{Basic formulation}

\subsection{Homogenization method}

The homogenization method is based on a two-scale asymptotic expansion of material behaviors with periodic unit cells. The overall properties of an elastic body can be described by considering two different scales: the macroscopic or global level x, and the microscopic or local level y. The global level $\mathrm{x}$ is related to the local level $\mathrm{y}$ by $y=x / \varepsilon$, where $\varepsilon$ is a very small positive number. Using a double-scale asymptotic expansion, the displacement field can be written as:

$$
u^{\varepsilon}=u^{0}(x, y)+\varepsilon^{1} u^{1}(x, y)+\varepsilon^{2} u^{2}(x, y)+\cdots
$$

Introducing Eq.(1) into the virtual displacement equation of the general elasticity problem and equating the terms with the same power of $\varepsilon$, after a series of derivation, it yields,

$$
E_{i j k l}^{H}(x)=\frac{1}{|Y|} \int_{Y}\left(E_{i j k l}-E_{i j p m} \frac{\partial \chi_{p}^{k l}}{\partial y_{m}}\right) \mathrm{d} Y
$$

where $E_{i j k l}^{H}$ represents the equivalent homogenized elastic modulus. $|Y|$ denotes the volume of the unit cell. $\chi^{k l}$ is a Y-periodic admissible displacement field associated with load case $\mathrm{kl}$, which can be obtained from the following integral equation over the unit cell with periodic boundary conditions.

$$
\int_{Y} E_{i j p q} \frac{\partial \chi_{p}^{k l}}{\partial y_{q}} \frac{\partial v_{i}}{\partial y_{j}} d Y=\int_{Y} E_{i j k l} \frac{\partial v_{i}}{\partial y_{j}} d Y \quad \forall v \in Y
$$

where $v$ is set to be a admissible arbitrary displacement field. Numerically, $\chi^{k l}$ is computed over the unit cell by the FE analysis in which the corresponding loads are obtained as the discontinuity of elastic material properties along the interfaces between distinct constitutive phases. The detailed concepts and derivation are seen in Ref. [24, 25].

\subsection{Laminate plate theory}

A sandwich panel can be considered as a multi-layered plate when the sandwich core is homogenized by using the homogenization method. Therefore, the laminate plate theory $[26,27]$ can be used to analyze its bending response. According to the assumption of the laminate plate theory that the lines perpendicular to the surface of the laminate remain straight and perpendicular to the deformed surface as well. The functional forms of the displacements for the laminate plate are:

$$
\begin{aligned}
& u(x, y, z)=u_{0}(x, y)+z \bar{\alpha}(x, y) \\
& v(x, y, z)=v_{0}(x, y)+z \bar{\beta}(x, y) \\
& w(x, y, z)=w_{0}(x, y)
\end{aligned}
$$

where $u_{0}, v_{0}$ and $w_{0}$ are the displacements of the midplane (that is, the $x-y$ plane in Fig. 2 below) of the laminate plate on $x, y$ and $z$ direction respectively. The second terms in the first two equations are related to the rotations of the lineal element. In classical plate theory,

$$
\bar{\alpha}=-\frac{\partial w}{\partial x}, \quad \bar{\beta}=-\frac{\partial w}{\partial y}
$$

The equilibrium equations for the three dimensional elasticity can be written as follows:

$$
\begin{aligned}
& \frac{\partial \sigma_{x}}{\partial x}+\frac{\partial \sigma_{y x}}{\partial y}+\frac{\partial \sigma_{z x}}{\partial z}+F_{x}=0 \\
& \frac{\partial \sigma_{x y}}{\partial x}+\frac{\partial \sigma_{y}}{\partial y}+\frac{\partial \sigma_{z y}}{\partial z}+F_{y}=0 \\
& \frac{\partial \sigma_{x z}}{\partial x}+\frac{\partial \sigma_{y z}}{\partial y}+\frac{\partial \sigma_{z}}{\partial z}+F_{z}=0
\end{aligned}
$$


In classical laminate plate theory, we define and use stress resultants $(N)$, stress couples $(M)$, and shear resultants $(Q)$ for the overall plate.

$$
\left\{\begin{array}{l}
N_{x} \\
N_{y} \\
N_{x y} \\
Q_{x} \\
Q_{y}
\end{array}\right\}=\int_{-h / 2}^{+h / 2}\left\{\begin{array}{l}
\sigma_{x} \\
\sigma_{y} \\
\sigma_{x y} \\
\sigma_{x z} \\
\sigma_{y z}
\end{array}\right\} d z,\left\{\begin{array}{l}
M_{x} \\
M_{y} \\
M_{x y}
\end{array}\right\}=\int_{-h / 2}^{+h / 2}\left\{\begin{array}{l}
\sigma_{x} \\
\sigma_{y} \\
\sigma_{x y}
\end{array}\right\} z d z
$$

Then the body force items $\left(F_{x}, F_{y}, F_{z}\right)$ are neglected. It is further assumed that the plate is composed of a laminated composite material that is mid-plane symmetric. From Eq.(6) and Eq.(7) through integrating term by term across each layer, the plate equilibrium equations for the bending of the plate can be expressed as

$$
\begin{gathered}
\frac{\partial M_{x}}{\partial x}+\frac{\partial M_{x y}}{\partial y}-Q_{x}=0 \\
\frac{\partial M_{x y}}{\partial x}+\frac{\partial M_{y}}{\partial y}-Q_{y}=0 \\
\frac{\partial Q_{x}}{\partial x}+\frac{\partial Q_{y}}{\partial y}+P(x, y)=0
\end{gathered}
$$

Eq.(8) and Eq.(9) can be substituted into Eq.(10), which generates

$$
\frac{\partial^{2} M_{x}}{\partial x^{2}}+2 \frac{\partial^{2} M_{x y}}{\partial x \partial y}+\frac{\partial^{2} M_{y}}{\partial y^{2}}=-P(x, y)
$$

From the following equation:

$$
\left[\begin{array}{l}
N \\
M
\end{array}\right]=\left[\begin{array}{ll}
A & B \\
B & D
\end{array}\right]\left[\begin{array}{l}
\varepsilon \\
k
\end{array}\right]
$$

and according to Eq.(4) and Eq.(5) and the relations among displacements, strains and stresses of the laminate plate, we obtain:

$$
\begin{aligned}
& M_{x}=D_{11} k_{x}+D_{12} k_{y} \\
& M_{y}=D_{12} k_{x}+D_{22} k_{y} \\
& M_{x y}=2 D_{66} k_{x y}
\end{aligned}
$$

where

$$
\begin{aligned}
& k_{x}=\frac{\partial \bar{\alpha}}{\partial x}=-\frac{\partial^{2} w}{\partial x^{2}} \\
& k_{y}=\frac{\partial \bar{\beta}}{\partial y}=-\frac{\partial^{2} w}{\partial y^{2}} \\
& k_{x y}=\frac{1}{2}\left(\frac{\partial \bar{\alpha}}{\partial x}+\frac{\partial \bar{\beta}}{\partial y}\right)=-\frac{\partial^{2} w}{\partial x \partial y}
\end{aligned}
$$

$$
D_{i j}=\frac{1}{3} \sum_{k=1}^{N}\left(Q_{i j}\right)\left[h_{k}^{3}-h_{k-1}^{3}\right]
$$

Here the principal material directions $(1,2,3)$ coincide with the $x-y-z$ coordinate system. The $Q_{i j}$ quantities are the stiffness matrix quantities that have the following simple forms by ignoring the fine accuracy.

$$
\begin{aligned}
& Q_{11}=E_{11} /\left(1-v_{12} v_{21}\right) \\
& Q_{22}=E_{22} /\left(1-v_{12} v_{21}\right) \\
& Q_{12}=Q_{21}=v_{21} E_{11} /\left(1-v_{12} v_{21}\right)=v_{12} E_{22} /\left(1-v_{12} v_{21}\right) \\
& Q_{66}=G_{12}
\end{aligned}
$$

Substitute Eq.(13) and Eq.(14) into Eq.(11), which results in:

$$
D_{11} \frac{\partial^{4} w}{\partial x^{4}}+2\left(D_{12}+2 D_{66}\right) \frac{\partial^{4} w}{\partial x^{2} \partial y^{2}}+D_{22} \frac{\partial^{4} w}{\partial y^{4}}=P(x, y)
$$

According to Eq.(17), the bending response of a sandwich panel, except transverse shear deformation and coupling terms subjected to a lateral distributed load $P(x, y)$, can be obtained by the Levy and Navier solution.

\section{Bending responses of sandwich panels}

\subsection{Sandwich panels with the honeycomb cores}

\subsubsection{Hexagonal and rectangular cores}

Sandwich panels with the hexagonal and rectangular honeycomb cores, as shown in Fig.2, are simply supported on the left and right side. The line load $\mathrm{P}=100 \mathrm{~N} / \mathrm{m}$ is imposed on the center of the plate. The sandwich panel has the dimensions assigned as: width $a=0.8865 \mathrm{~m}$, length $\mathrm{b}=1.5354 \mathrm{~m}$, thickness $\mathrm{h}_{\mathrm{u}}=\mathrm{h}_{\mathrm{l}}=0.0125 \mathrm{~m}, \mathrm{~h}_{\mathrm{c}}=0.0375 \mathrm{~m}$ (u-upper skin, llower skin, c-core), and the material properties: $\mathrm{E}_{\mathrm{u}}=\mathrm{E}_{\mathrm{l}}=2.0 \mathrm{GPa}, \mathrm{E}_{\mathrm{c}}=0.91 \mathrm{GPa}$. These two honeycomb cores have the same volume fraction $26.53 \%$.

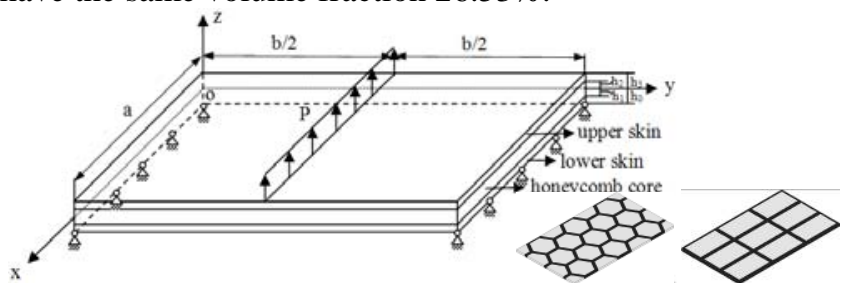

Fig.2. Sandwich panel with hexagonal and rectangular cores

The effecitive material properties of hexagonal honeycomb core are obtained by the 3D homogenization method.

$E_{x}^{H}=3.118352 \mathrm{E}+07, E_{y}^{H}=3.116449 \mathrm{E}+07, E_{z}^{H}=2.414286 \mathrm{E}+08$

$G_{x y}^{H}=8.770264 \mathrm{E}+06, G_{y z}^{H}=5.272060 \mathrm{E}+07, G_{x z}^{H}=5.273506 \mathrm{E}+07$

$v_{x y}^{H}=7.818590 \mathrm{E}-01, v_{x z}^{H}=3.874876 \mathrm{E}-02, v_{y z}^{H}=3.872511 \mathrm{E}-02$ 
The effecitive material properties of rectangular honeycomb core are

$E_{x}^{H}=1.714326 \mathrm{E}+08, E_{y}^{H}=1.029486 \mathrm{E}+08, E_{z}^{H}=2.414286 \mathrm{E}+08$

$G_{x y}^{H}=1.425520 \mathrm{E}+06, G_{y z}^{H}=3.840819 \mathrm{E}+07, G_{x z}^{H}=6.499972 \mathrm{E}+07$

$v_{x y}^{H}=2.119053 \mathrm{E}-02, v_{x z}^{H}=2.130228 \mathrm{E}-01, v_{y z}^{H}=1.279243 \mathrm{E}-01$

According to the boundary conditions on those edges: $\mathrm{w}(\mathrm{x}$, $0)=0$, $w(x, b)=0$, and $\operatorname{My}(x, 0)=0, \operatorname{My}(x, b)=0$, Levy assumed the following solution form of Eq.(17): a single infinite half range sine series:

$$
w(x, y)=\sum_{n=1}^{\infty} \phi_{n}(x) \sin \frac{n \pi x}{b}
$$

The load $P(x, y)$ is also expanded in terms of a half range sine series. Then, by substituting Eq.(20) into Eq.(17), the equation concerning $\phi_{n}(x)$ is obtained. Its solution is composed of the particular solution $\phi_{n_{p}}(x)$ and the homogenous solution $\phi_{n_{H}}(x)$ that has three different forms depending on the relative plate stiffness in various directions.

The total potential energy is:

$$
U=\int_{0}^{a} w(x, b / 2) P(x, b / 2) d x
$$

Via the calculation, the Levy solution converges when the expansion number $\mathrm{n}$ equals to 5 . The maximum displacement module is $2.94 \times 10-4 \mathrm{~m}$, and the total potential energy is $2.44 \times 10-2 \mathrm{~N} \cdot \mathrm{m}$ for the hexagonal core. The maximum displacement module is $2.622 \times 10-4 \mathrm{~m}$, and the total potential energy is $2.41 \times 10-2 \mathrm{~N} \cdot \mathrm{m}$ for the rectangular core. The deformation of sandwich panels is shown in Fig.3.

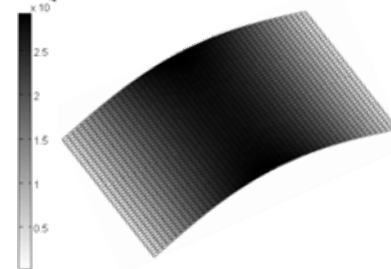

(a) Hexagonal cores (b) Rectangular cores

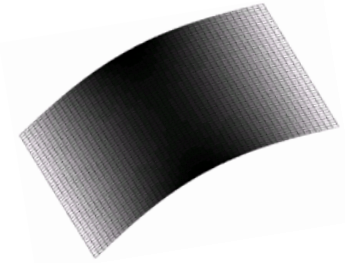

Fig.3. Levy solution of sandwich panel with homogenized cores

The bending response of the sandwich panel made of three-layered homogeneous media is obtained via the finite element software SAMCEF®. The maximum displacement module is $2.57 \times 10-4 \mathrm{~m}$, and the total potential energy is $2.139 \times 10-2 \mathrm{~N} \cdot \mathrm{m}$ for the hexagonal core. The maximum displacement module is $2.499 \times 10-4 \mathrm{~m}$, and the total potential energy is $2.0885 \times 10-2 \mathrm{~N} \cdot \mathrm{m}$ for the rectangular core. The detailed deformation is shown in Fig.4.

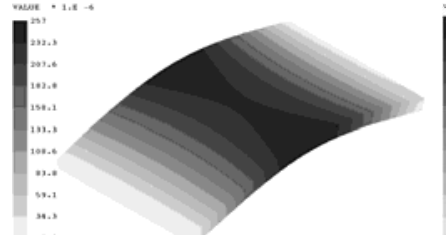

(a)

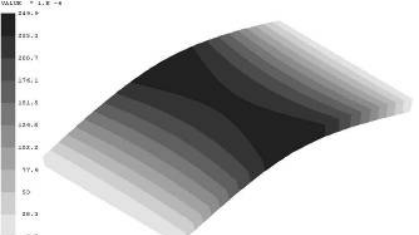

(b)
Fig.4. FE solution of sandwich panel with the homogenized (a) hexagonal and (b) rectangular cores

Table 1. Bending deflections of sandwich panels with different size hexagonal cores

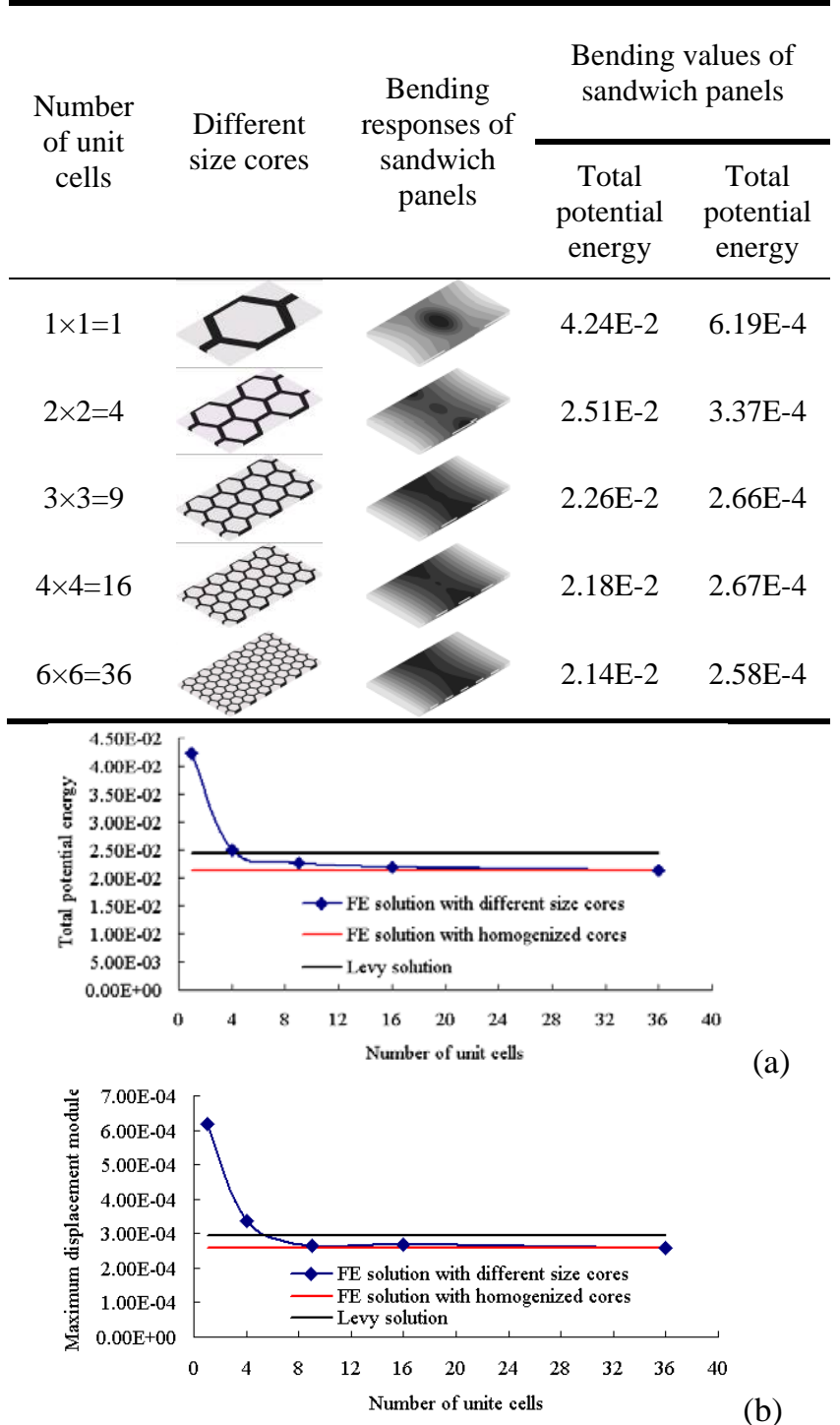

Fig.5 (a) Total potential energy and (b) Maximum displacement module of sandwich panel with the hexagonal core

Table 2. Bending deflections of sandwich panels with dif-

\begin{tabular}{|c|c|c|c|c|}
\hline \multirow{2}{*}{$\begin{array}{l}\text { Number } \\
\text { of unit } \\
\text { cells }\end{array}$} & \multirow{2}{*}{$\begin{array}{c}\text { Different } \\
\text { size cores }\end{array}$} & \multirow{2}{*}{$\begin{array}{l}\text { Bending } \\
\text { responses } \\
\text { of } \\
\text { sandwich } \\
\text { panels }\end{array}$} & \multicolumn{2}{|c|}{$\begin{array}{l}\text { Bending values of } \\
\text { sandwich panels }\end{array}$} \\
\hline & & & $\begin{array}{c}\text { Total } \\
\text { potential } \\
\text { energy }\end{array}$ & $\begin{array}{c}\text { Total } \\
\text { potential } \\
\text { energy }\end{array}$ \\
\hline
\end{tabular}
ferent size rectangular cores 


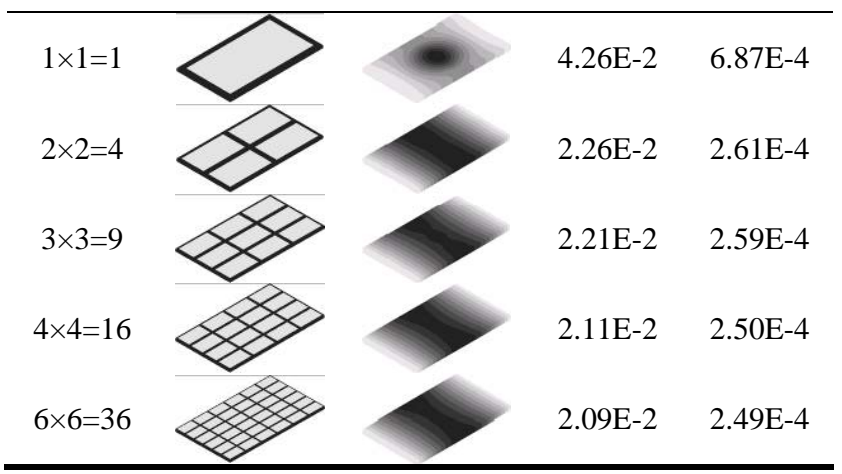

The finite element models of sandwich panels with the different size hexagonal and rectangular cores are built and their bending responses are analyzed as shown in Table 1, 2 and Fig 5, 6.

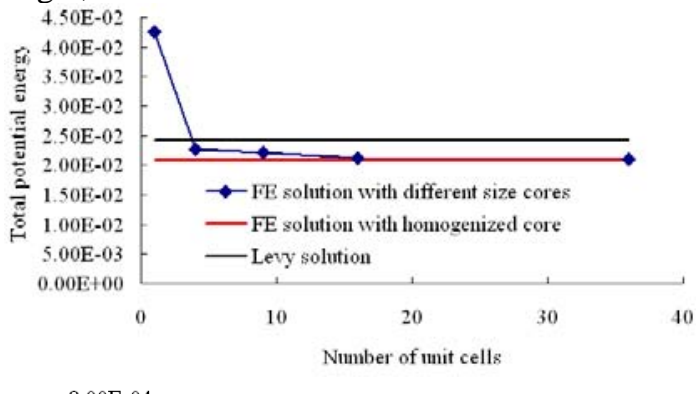

(a)

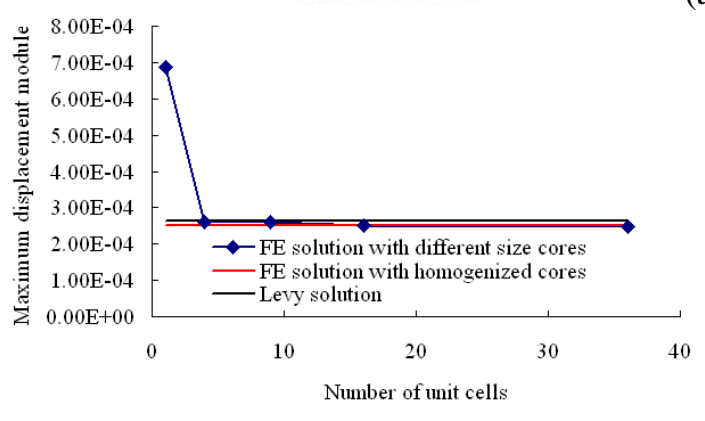

(b)

Fig.6. (a) Total potential energy and (b) Maximum displacement module of sandwich panel with the rectangular core

\subsubsection{Square and rhombic cores}

Consider sandwich panels with the square and rhombic honeycomb cores as shown in Fig.7. All the four edges are simply supported. The uniform surface loading $q=100 \mathrm{~N} / \mathrm{m}^{2}$ is applied on the upper surface. The sandwich panel has the dimensions assigned as: $\mathrm{a}=1.1 \mathrm{~m}, \mathrm{~h}_{\mathrm{u}}=\mathrm{h}_{\mathrm{l}}=0.0125 \mathrm{~m}$, $\mathrm{h}_{\mathrm{c}}=0.0375 \mathrm{~m}$ (u-upper skin, l-lower skin, c-core), and the material properties: $\mathrm{E}_{\mathrm{u}}=\mathrm{E}_{\mathrm{l}}=2.0 \mathrm{GPa}, \mathrm{E}_{\mathrm{c}}=0.91 \mathrm{GPa}$. These two honeycomb cores have the same volume fraction $17.35 \%$.

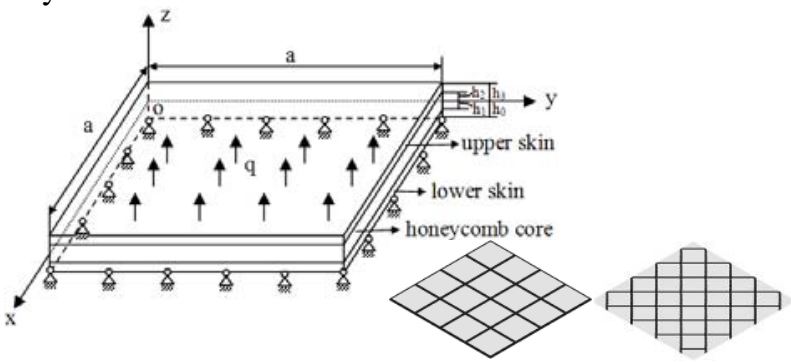

Fig.7. Sandwich panel with square and rhombic cores

The effecitive properties of the square honeycomb core are obtained by the homogenization method.
$E_{x}^{H}=8.769525 \mathrm{E}+07, E_{y}^{H}=8.769525 \mathrm{E}+07, E_{z}^{H}=1.579339 \mathrm{E}+08$

$G_{x y}^{H}=4.154834 \mathrm{E}+05, G_{y z}^{H}=3.270143 \mathrm{E}+07, G_{x z}^{H}=3.270143 \mathrm{E}+07$

$v_{x y}^{H}=-6.337963 \mathrm{E}-03, v_{x z}^{H}=1.665797 \mathrm{E}-01, v_{y z}^{H}=1.665797 \mathrm{E}-01$

The effecitive properties of the square honeycomb core are:

$E_{x}^{H}=2.142905 \mathrm{E}+06, E_{y}^{H}=2.149689 \mathrm{E}+06, E_{z}^{H}=1.579339 \mathrm{E}+08$

$G_{x y}^{H}=4.454896 \mathrm{E}+07, G_{y z}^{H}=3.305019 \mathrm{E}+07, G_{x z}^{H}=3.295121 \mathrm{E}+07$

$v_{x y}^{H}=9.740973 \mathrm{E}-01, v_{x z}^{H}=4.070510 \mathrm{E}-03, v_{y z}^{H}=4.083396 \mathrm{E}-03$

According to the boundary conditions on the four edges, in the Navier approach we can simply expand the deflection, $\mathrm{w}(\mathrm{x}, \mathrm{y})$ and the applied uniform loading, $\mathrm{q}(\mathrm{x}, \mathrm{y})$, into a doubly infinite half range sine series.

$$
\begin{gathered}
w(x, y)=\sum_{m=1}^{\infty} \sum_{n=1}^{\infty} \frac{a^{4} q_{m n}}{D \pi^{4}} \sin \frac{m \pi x}{a} \sin \frac{n \pi y}{a} \\
q(x, y)=\sum_{m=1}^{\infty} \sum_{n=1}^{\infty} q_{m n} \sin \frac{m \pi x}{a} \sin \frac{n \pi y}{a}
\end{gathered}
$$

where

$$
\begin{gathered}
q_{m n}=\frac{16 q}{m n \pi^{2}}, \quad m, n=1,3,5, \ldots \\
D=D_{11}\left(\frac{m}{a}\right)^{4}+2\left(D_{12}+2 D_{66}\right)\left(\frac{m n}{a^{2}}\right)^{2}+D_{22}\left(\frac{n}{a}\right)^{4}
\end{gathered}
$$

The total potential energy is:

$$
U=\iint_{A} w(x, y) q(x, y) d x d y
$$

Via the calculation, the Navier solution converges when the expansion number $n$ is 7. The maximum displacement module is $1.687 \times 10^{-5} \mathrm{~m}$, and the total potential energy is $1.4 \times 10^{-3} \mathrm{~N} \cdot \mathrm{m}$ for the square core. The maximum displacement module is $1.682 \times 10^{-5} \mathrm{~m}$, and the total potential energy is $1.4 \times 10^{-3} \mathrm{~N} \cdot \mathrm{m}$ for the rhombic core. The deformation of sandwich panels for the detail is shown in Fig.8.

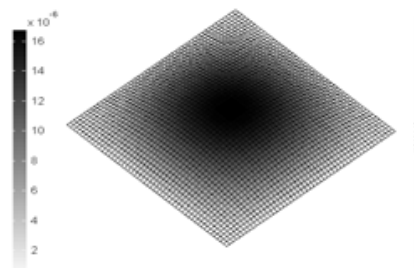

(a) Square cores

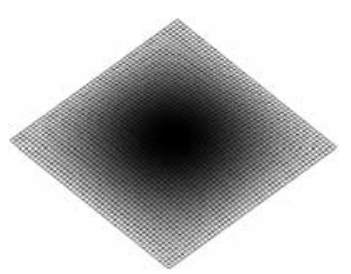

(b) Rhombic cores
Fig.8. Navier solutions of sandwich panels with homogenized cores 


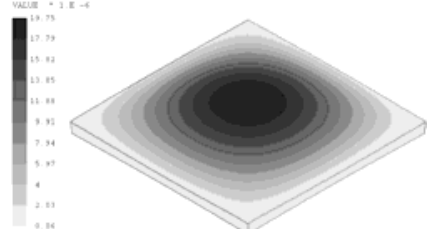

(a) Square cores

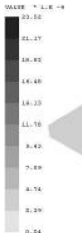

(b) Rhombic cores
Fig.9. FE solutions of sandwich panels with homogenized cores

Likewise, the finite element models of sandwich panels with the different size square and rhombic cores are built and their bending responses are analyzed as shown in Table 3, 4 and Fig.10, 11.

Similar to the previous analysis, for this kind of sandwich panel made of three-layered homogeneous media, the maximum displacement module is $1.975 \times 10^{-5} \mathrm{~m}$, and the total potential energy is $9.868 \times 10^{-4} \mathrm{~N} \cdot \mathrm{m}$ for the square core. The maximum displacement module is $2.352 \times 10^{-5} \mathrm{~m}$, and the total potential energy is $1.246839 \times 10^{-3} \mathrm{~N} \cdot \mathrm{m}$ for the rhombic core. The deformation is shown in Fig.9.

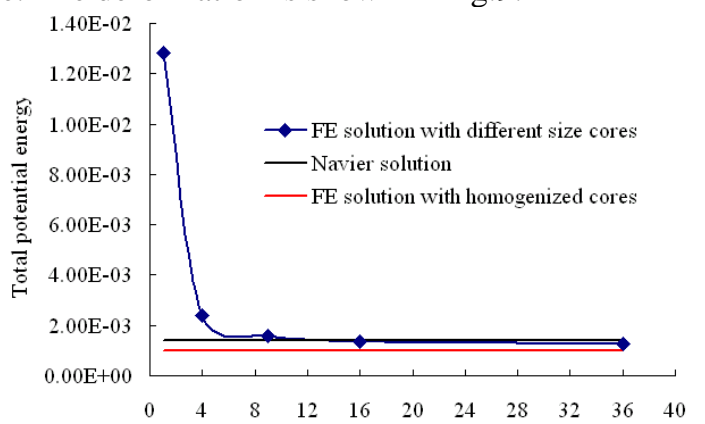

(a)

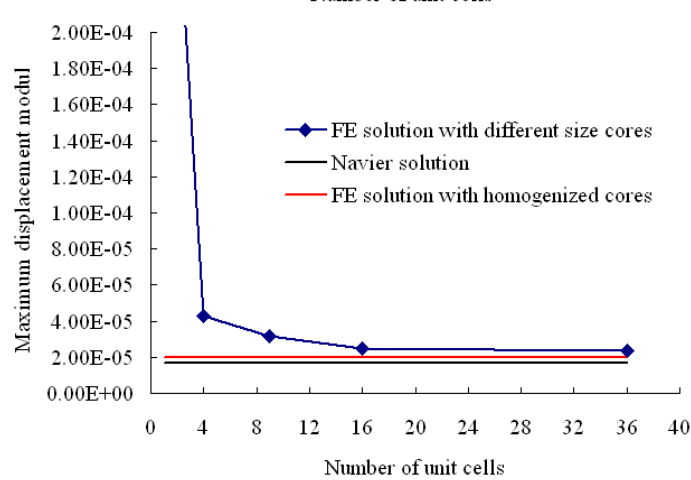

(b)

Fig.10. (a) Total potential energy and (b) Maximum displacement module of sandwich panel with the square core

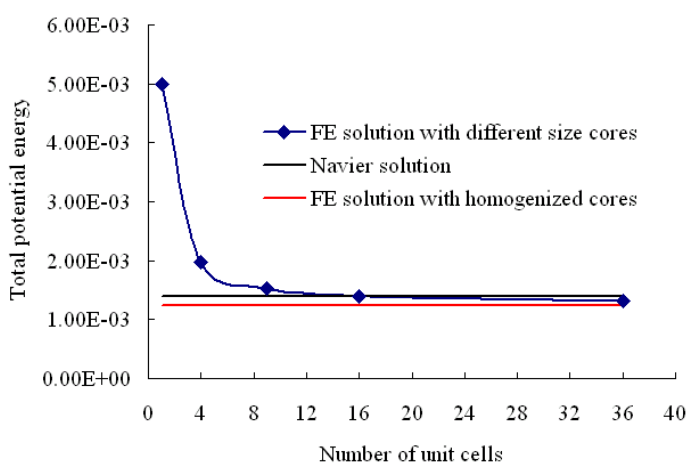

(a)

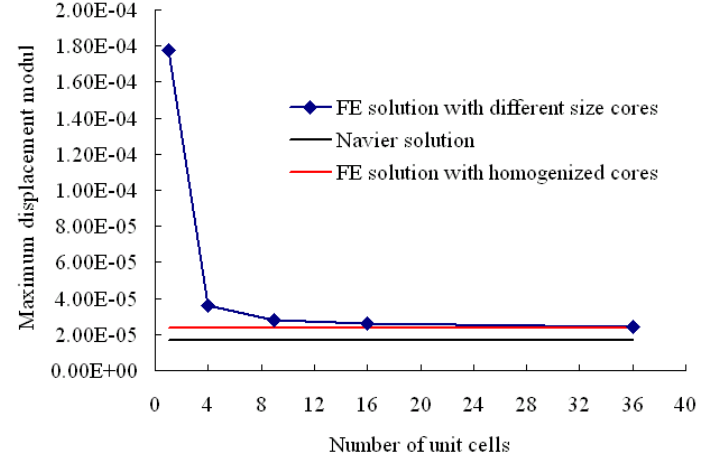

(b)

Fig.11. (a) Total potential energy and (b) Maximum displacement module of sandwich panel with the rhombic core

Table 3. Bending deflections of sandwich panel with different size square cores

Number
of unit
cells

Table 4. Bending deflections of sandwich panel with different size rhombic cores

\begin{tabular}{|c|c|c|c|c|}
\hline \multirow{2}{*}{$\begin{array}{c}\text { Number } \\
\text { of unit } \\
\text { cells }\end{array}$} & \multirow{2}{*}{$\begin{array}{c}\text { Different } \\
\text { size cores }\end{array}$} & \multirow{2}{*}{$\begin{array}{c}\text { Bending } \\
\text { responses } \\
\text { of sand- } \\
\text { wich pa- } \\
\text { nels }\end{array}$} & \multicolumn{2}{|c|}{$\begin{array}{l}\text { Bending values of } \\
\text { sandwich panels }\end{array}$} \\
\hline & & & $\begin{array}{c}\text { Total } \\
\text { potential } \\
\text { energy }\end{array}$ & $\begin{array}{c}\text { Maximum } \\
\text { displace- } \\
\text { ment } \\
\text { module }\end{array}$ \\
\hline $1 \times 1=1$ & & ? & $5.0 \mathrm{E}-3$ & $1.78 \mathrm{E}-4$ \\
\hline $2 \times 2=4$ & & & $1.98 \mathrm{E}-3$ & $0.36 \mathrm{E}-4$ \\
\hline $3 \times 3=9$ & & & $1.53 \mathrm{E}-3$ & $0.28 \mathrm{E}-4$ \\
\hline $4 \times 4=16$ & & & $1.40 \mathrm{E}-3$ & $0.26 \mathrm{E}-4$ \\
\hline $6 \times 6=36$ & & & $1.31 \mathrm{E}-3$ & $0.25 \mathrm{E}-4$ \\
\hline
\end{tabular}

\subsubsection{Discussion}


According to the figures and tables in the above two examples, it is found that bending response of sandwich panel tends to a limit case with the decreasing size of honeycomb core. This limit case is approximately the bending response of sandwich panel with homogenized cores with the same boundary conditions. At the same time, we also find that the coincidence between Levy solution and FE solution with homogenized hexagonal cores is worse than that between Navier solution and FE solution with homogenized square cores. The reason lies in the fact that the ratio of the span dimensions to thickness $\left(\alpha=a /\left(h_{u}+h_{c}+h_{l}\right)\right)$ is 14.184 for the hexagonal core and 17.6 for the square core. According to the basic assumption of the laminate plate theory, the classical lamination theory is only valid for thin laminates with small displacement in the transverse direction [26]. Therefore, when the ratio $\alpha$ increases, the theoretical solution is closer to the finite element solution equally well with the homogenized core.

Moreover, the bending deflection of sandwich panel with the rectangular cores is smaller than the hexagonal cores under the boundary condition of three points bending when the number of core unit cells rises or with the homogenized core. Comparing their effective elastic constants, we can find that the elastic moduli $E_{y}^{H}$ and $G_{x z}^{H}$ of the rectangular core are bigger than the hexagonal core, which play the leading role in the three points bending. In another example, the bending deflection of sandwich panel with the square cores is smaller than the rhombic cores with the four simplysupported edges by the finite element analysis. Similarly comparing their effective elastic constants, we can see that the effective elastic moduli in $\mathrm{x}$ and $\mathrm{y}$ directions of the square core are bigger than the rhombic core, but the effective shear moduli in $\mathrm{y}-\mathrm{z}$ and $\mathrm{x}-\mathrm{z}$ planes are close.

From these two cases, we can see that the configuration of unit cells in sandwich cores affects the bending performance of sandwich panels although they have the same volume fraction.

\subsection{Sandwich panels with the corrugated cores}

Table 5. Bending deflections of sandwich structures with different size circle cores

\begin{tabular}{|c|c|c|c|c|}
\hline \multirow{2}{*}{$\begin{array}{l}\text { Number } \\
\text { of unit } \\
\text { cells }\end{array}$} & \multirow{2}{*}{$\begin{array}{l}\text { Different } \\
\text { size cores }\end{array}$} & \multirow{2}{*}{$\begin{array}{c}\text { Bending } \\
\text { responses } \\
\text { of sand- } \\
\text { wich struc- } \\
\text { tures }\end{array}$} & \multicolumn{2}{|c|}{$\begin{array}{l}\text { Bending values of } \\
\text { sandwich structures }\end{array}$} \\
\hline & & & $\begin{array}{c}\text { Total } \\
\text { potential } \\
\text { energy }\end{array}$ & $\begin{array}{c}\text { Maximum } \\
\text { displace- } \\
\text { ment } \\
\text { module }\end{array}$ \\
\hline $1 \times 6=6$ & & & $1.26 \mathrm{E} 2$ & 8.64E-2 \\
\hline $2 \times 12=24$ & 808800800888 & & 7.12E1 & $4.82 \mathrm{E}-2$ \\
\hline $3 \times 18=54$ & 8586888080808080 & & $6.45 \mathrm{E} 1$ & 4.36E-2 \\
\hline $4 \times 24=96$ & 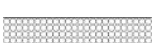 & & 5.94E1 & $4.01 \mathrm{E}-2$ \\
\hline
\end{tabular}

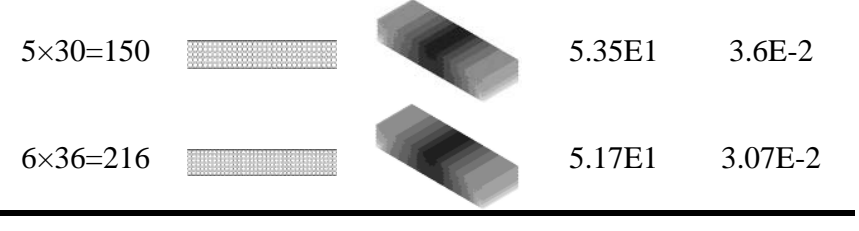

In this section, the bending responses of sandwich panels with corrugated cores are analyzed with different sizes. Two forms of the cores i.e. the circle-core and the X-core are involved here. The boundary condition of three points bending is the same as Fig.2. The material properties of two sandwich panels are assigned as: $\mathrm{E}_{\mathrm{u}}=\mathrm{E}_{\mathrm{l}}=2$.0GPa for upper and lower skins, $E_{c}=0.91 \mathrm{GPa}$ for cores. The difference between the two sandwich panels lies in that the simply supported sides are parallel to the extended direction of the unit cell for the circle-core, and vertical to the extended direction of the unit cell for the X-core. Here, only finite element solutions with the different size cores and homogenized cores are obtained. The levy method isn't adopted because the ratio of the span dimensions to thickness of sandwich panels $\left(\alpha=W /\left(h_{u}+h_{c}+h_{l}\right)\right)$ is 1.9 for circle core and 2.857 for Xcore. The laminate plate theory is no more applicable by the validation of examples in section 3.1.

\subsubsection{Circle-core}

For the sandwich structure with the circle core, the dimensions are set to be: length $\mathrm{L}=2.4 \mathrm{~m}$, width $\mathrm{W}=0.8 \mathrm{~m}$, thickness $h_{u}=h_{l}=0.01 m, h_{c}=0.40 m$ (u-upper skin, l-lower skin, c-core).

The effecitive properties of the circle core are obtained by the homogenization method as follows.

$$
\begin{aligned}
& E_{x}^{H}=4.388174 \mathrm{E}+05, E_{y}^{H}=4.461644 \mathrm{E}+05, E_{z}^{H}=6.961283 \mathrm{E}+07 \\
& G_{x y}^{H}=5.557200 \mathrm{E}+05, G_{y z}^{H}=1.132639 \mathrm{E}+07, G_{x z}^{H}=1.132639 \mathrm{E}+07 \\
& v_{x y}^{H}=8.938214 \mathrm{E}-01, v_{x z}^{H}=1.891106 \mathrm{E}-03, v_{y z}^{H}=1.922768 \mathrm{E}-03
\end{aligned}
$$

Bending deflections of sandwich structure with the homogenized core is shown in Fig.12.

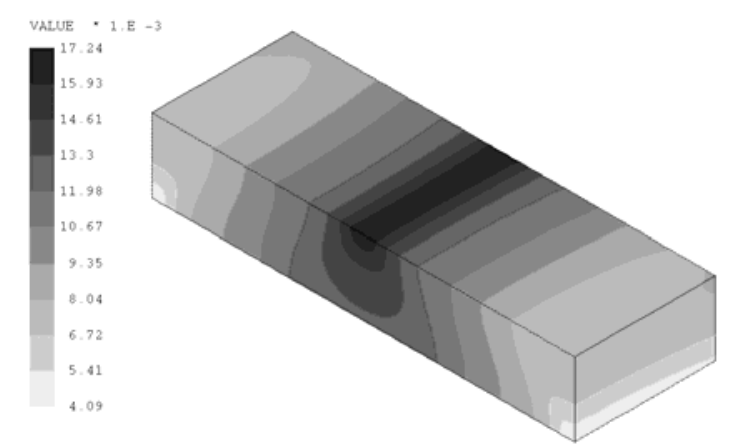

Fig.12. Finite element solution of sandwich structure with the homogenized core 

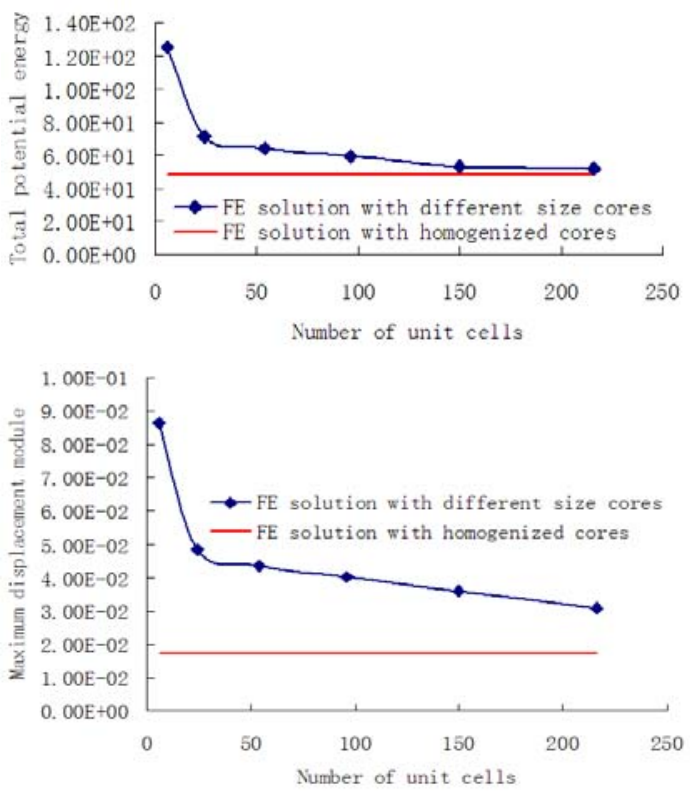

(a)

Fig.13. (a) Total potential energy and (b) Maximum displacement module of sandwich structure with the circle core

In Fig.13, it shows the values of the potential energy and the maximum displacement versus the number of the unit cells that have been used in the sandwich core.

\subsubsection{X-core}

For the sandwich structure with the $\mathrm{X}$-core, the dimensions are: length $\mathrm{L}=2.0 \mathrm{~m}$, width $\mathrm{W}=1.2 \mathrm{~m}$, thickness $\mathrm{h}_{\mathrm{u}}=\mathrm{h}_{\mathrm{l}}=0.01 \mathrm{~m}, \mathrm{~h}_{\mathrm{c}}=0.4 \mathrm{~m}$ (u-upper skin, l-lower skin, c-core).

The effecitive properties of the X-core are obtained by the homogenization method.

$$
E_{x}^{H}=3.927310 \mathrm{E}+04, E_{y}^{H}=1.666816 \mathrm{E}+05, E_{z}^{H}=5.940933 \mathrm{E}+07
$$$$
G_{x y}^{H}=2.988478 \mathrm{E}+06, G_{y z}^{H}=1.542861 \mathrm{E}+07, G_{x z}^{H}=8.097270 \mathrm{E}+06
$$$$
v_{x y}^{H}=4.839506 \mathrm{E}-01, v_{x z}^{H}=1.983178 \mathrm{E}-04, v_{y z}^{H}=8.416942 \mathrm{E}-04
$$

The bending deformation of sandwich structure with the homogenized core is seen as Fig.14. And the values of the potential energy and the maximum displacement versus the number of the unit cells that have been used in the sandwich core are plotted as shown in Fig.15.

Table 6. Bending deflections of sandwich structures with different size $\mathrm{X}$-cores

\begin{tabular}{|c|c|c|c|c|}
\hline \multirow{2}{*}{$\begin{array}{l}\text { Number } \\
\text { of unit } \\
\text { cells }\end{array}$} & \multirow{2}{*}{$\begin{array}{l}\text { Different } \\
\text { size cores }\end{array}$} & \multirow{2}{*}{$\begin{array}{l}\text { Bending } \\
\text { responses } \\
\text { of sand- } \\
\text { wich struc- } \\
\text { tures }\end{array}$} & \multicolumn{2}{|c|}{$\begin{array}{l}\text { Bending values of } \\
\text { sandwich structures }\end{array}$} \\
\hline & & & $\begin{array}{c}\text { Total } \\
\text { potential } \\
\text { energy }\end{array}$ & $\begin{array}{c}\text { Maximum } \\
\text { displace- } \\
\text { ment } \\
\text { module }\end{array}$ \\
\hline $1 \times 4=4$ & & & $6.23 \mathrm{E}-3$ & 8.92E-5 \\
\hline $2 \times 8=16$ & & & $3.40 \mathrm{E}-3$ & $3.59 \mathrm{E}-5$ \\
\hline
\end{tabular}
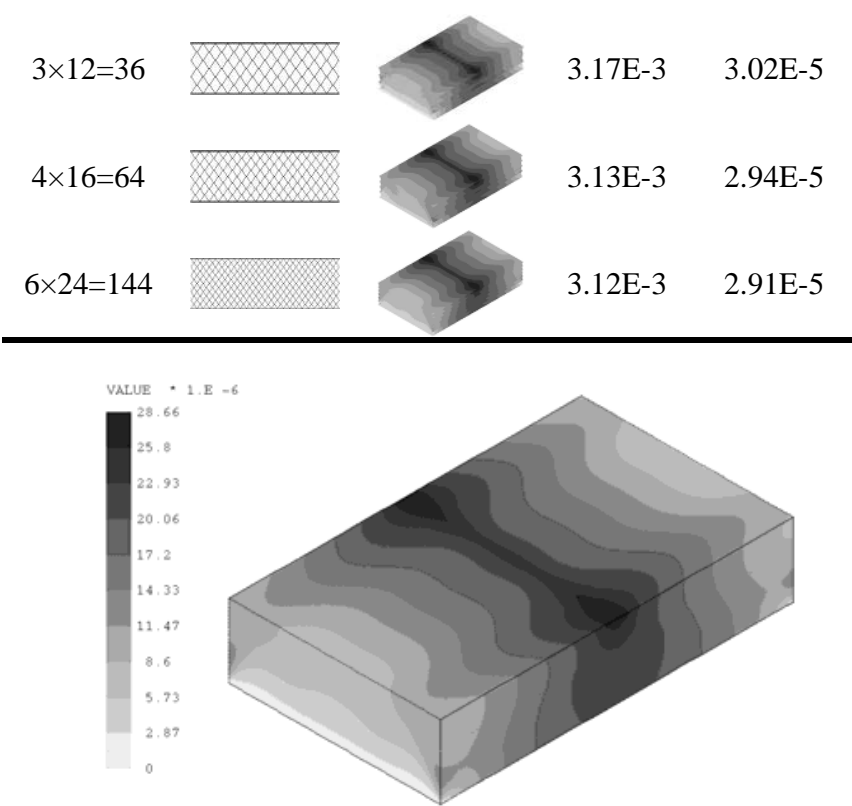

Fig.14. FE solution of sandwich structure with the homogenized core
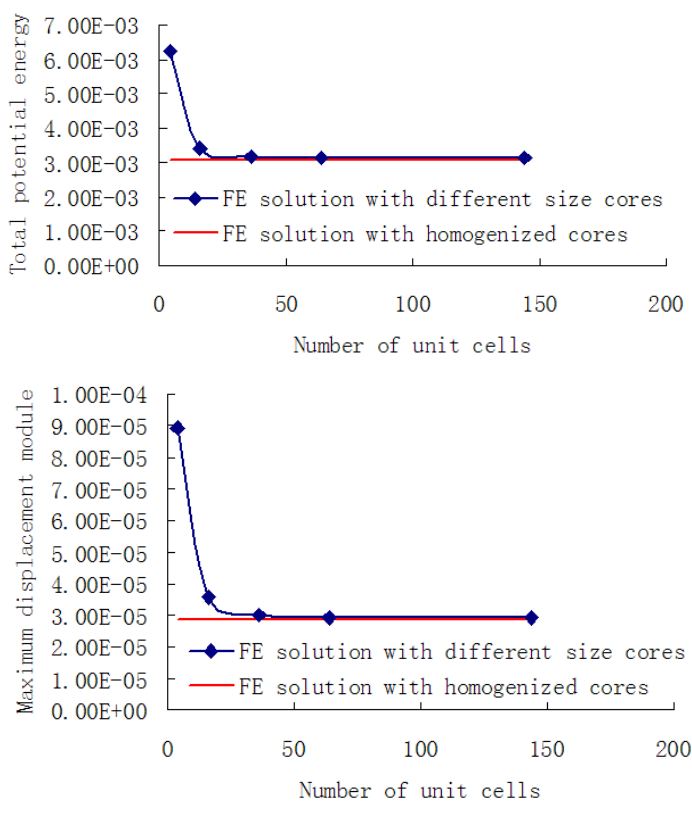

(a)

Fig.15. (a) Total potential energy and (b) Maximum displacement module of sandwich panel with the X-core

As known from Table 5, Table 6 and Fig.12, Fig.13, Fig.14 and Fig.15, the bending responses of sandwich structures with both circle cores and X-cores similarly converge to those obtained with homogenized cores when the sizes of honeycomb cores decrease. But the latter is faster and closer. There are two reasons. On the one hand, the latter ratio $\alpha$ of span dimensions to thickness is bigger. On the other hand, the simply supported sides are vertical to the extended direction of the unit cell for the $\mathrm{X}$-core so that they are more homogeneous than circle cores under action of the transverse line load.

Therefore, for both the honeycomb core and the corrugated core, the bending response of sandwich panel has the common regularity with the size effect that the overall bending stiffness gradually increases along with ratio of the spe- 
cimen size to the cell size. The conclusion is also verified by Ref. [21].

\section{Dynamic analysis of sandwich panels}

\subsection{Dynamic analysis of laminate plate including transverse shear deformation}

As given in [26], for the laminate plate simply supported on all four edges, the solutions for the flexural vibration may be written as

$$
\begin{aligned}
& w(x, y, t)=\sum_{m=1}^{\infty} \sum_{n=1}^{\infty} C_{m n} \sin \frac{m \pi x}{a} \sin \frac{n \pi y}{b} e^{i \omega t} \\
& \bar{\alpha}(x, y, t)=\sum_{m=1}^{\infty} \sum_{n=1}^{\infty} A_{m n} \cos \frac{m \pi x}{a} \sin \frac{n \pi y}{b} e^{i \omega t} \\
& \bar{\beta}(x, y, t)=\sum_{m=1}^{\infty} \sum_{n=1}^{\infty} B_{m n} \sin \frac{m \pi x}{a} \cos \frac{n \pi y}{b} e^{i \omega t}
\end{aligned}
$$

The governing differential equations including the transverse shear deformation and neglecting the rotatory inertia terms are following

$$
\begin{gathered}
D_{11} \frac{\partial^{2} \bar{\alpha}}{\partial x^{2}}+D_{66} \frac{\partial^{2} \bar{\alpha}}{\partial y^{2}}+\left(D_{12}+D_{66}\right) \frac{\partial^{2} \bar{\beta}}{\partial x \partial y}-2 A_{55}\left(\bar{\alpha}+\frac{\partial w}{\partial x}\right)=0 \\
\left(D_{12}+D_{66}\right) \frac{\partial^{2} \bar{\alpha}}{\partial x \partial y}+D_{66} \frac{\partial^{2} \bar{\beta}}{\partial x^{2}}+D_{22} \frac{\partial^{2} \bar{\beta}}{\partial y^{2}}-2 A_{44}\left(\bar{\beta}+\frac{\partial w}{\partial y}\right)=0 \\
2 A_{55}\left(\frac{\partial \bar{\alpha}}{\partial x}+\frac{\partial^{2} w}{\partial x^{2}}\right)+2 A_{44}\left(\frac{\partial \bar{\beta}}{\partial y}+\frac{\partial^{2} w}{\partial y^{2}}\right)=\rho h \frac{\partial^{2} w}{\partial t^{2}}
\end{gathered}
$$

where $\mathrm{h}$ is the thickness of laminate plate and

$$
\begin{gathered}
\rho=\frac{1}{h} \sum_{k=1}^{N} \rho_{k}\left(h_{k}-h_{k-1}\right) \\
A_{i j}=\frac{5}{4} \sum_{k=1}^{N}\left(\bar{Q}_{i j}\right)_{k}\left[h_{k}-h_{k-1}-\frac{4}{3}\left(h_{k}^{3}-h_{k-1}^{3}\right) \frac{1}{h^{2}}\right] \quad i, j=4,5
\end{gathered}
$$

Substituting the solutions (Eq.(31)-Eq.(33)) into the governing equations (Eq.(34)-Eq.(36)) results in a set of homogeneous equations as follows

$$
\left[\begin{array}{lll}
L_{11} & L_{12} & L_{13} \\
L_{12} & L_{22} & L_{23} \\
L_{13} & L_{23} & L_{33}^{\prime}
\end{array}\right]\left\{\begin{array}{l}
A_{m n} \\
B_{m n} \\
C_{m n}
\end{array}\right\}=\left\{\begin{array}{l}
0 \\
0 \\
0
\end{array}\right\}
$$

where $L_{33}^{\prime}=L_{33}-\rho h \omega_{m n}^{2}$.

The square of the remaining natural frequency can be obtained by solving the above homogeneous equations.

$$
\omega_{m n}^{2}=\frac{\left(L_{11} L_{22}-L_{12}^{2}\right) L_{33}+2 L_{12} L_{23} L_{13}-L_{22} L_{13}^{2}-L_{11} L_{23}^{2}}{\rho h\left(L_{11} L_{22}-L_{12}^{2}\right)}
$$

where, $\mathrm{m}$ and $\mathrm{n}$ are the number of $\mathrm{x}$ and $\mathrm{y}$ axial halfwaves respectively. If $\lambda_{m}=m \pi / a$ and $\lambda_{n}=n \pi / b$,

$$
\begin{gathered}
L_{11}=D_{11} \lambda_{m}^{2}+D_{66} \lambda_{n}^{2}+2 A_{55} \\
L_{12}=\left(D_{12}+D_{66}\right) \lambda_{m} \lambda_{n} \\
L_{13}=2 A_{55} \lambda_{m} \\
L_{22}=D_{66} \lambda_{m}^{2}+D_{22} \lambda_{n}^{2}+2 A_{44} \\
L_{23}=2 A_{44} \lambda_{n} \\
L_{33}=2 A_{55} \lambda_{m}^{2}+2 A_{44} \lambda_{n}^{2}
\end{gathered}
$$

\subsection{Sandwich panel with hexagonal and rectan- gular honeycomb cores}

Sandwich panels with the hexagonal and rectangular honeycomb cores, as shown in Fig.2, are simply supported on the four bottom edges. The dimensions of the sandwich panel are following as: width $a=0.8865 \mathrm{~m}$, length $\mathrm{b}=1.5354 \mathrm{~m}$, thickness $h_{u}=h_{1}=0.01 m, h_{c}=0.03 m$ (u-upper skin, l-lower skin, and c-core). The elastic moduli of the upper and lower skins are $210 \mathrm{GPa}$. The density is $7800 \mathrm{~kg} / \mathrm{m}^{3}$. For the core, the elastic modulus is $75 \mathrm{GPa}$ and the density is $2700 \mathrm{~kg} / \mathrm{m}^{3}$ (solid or black part). In order to calculate the effective elastic constants of sandwich core, we assume that the void or white part is a very weak material: the elastic modulus is $0.00001 \mathrm{GPa}$ and density is $0.00001 \mathrm{~kg} / \mathrm{m}^{3}$.

The effective material properties of hexagonal honeycomb core are obtained by the 3D homogenization method.

$E_{x}^{H}=2.570071 \mathrm{E}+09, E_{y}^{H}=2.568502 \mathrm{E}+09, E_{z}^{H}=1.989796 \mathrm{E}+10$ $G_{x y}^{H}=7.228240 \mathrm{E}+08, G_{y z}^{H}=4.345104 \mathrm{E}+09, G_{x z}^{H}=4.346297 \mathrm{E}+09$ $v_{x y}^{H}=7.818590 \mathrm{E}-01, v_{x z}^{H}=3.874876 \mathrm{E}-02, v_{y z}^{H}=3.872511 \mathrm{E}-02$

The effective material properties of rectangular honeycomb core are

$$
\begin{aligned}
& E_{x}^{H}=1.412906 \mathrm{E}+10, E_{y}^{H}=8.484773 \mathrm{E}+09, E_{z}^{H}=1.989796 \mathrm{E}+10 \\
& G_{x y}^{H}=1.174879 \mathrm{E}+08, G_{y z}^{H}=3.165510 \mathrm{E}+09, G_{x z}^{H}=5.357120 \mathrm{E}+09 \\
& v_{x y}^{H}=2.119053 \mathrm{E}-02, v_{x z}^{H}=2.130228 \mathrm{E}-01, v_{y z}^{H}=1.279243 \mathrm{E}-01
\end{aligned}
$$

And the effective density of hexagonal honeycomb core is following,

$$
\rho_{\mathrm{c}}=\left(\left(S_{T}-S_{\text {void }}\right) \times 2700+S_{\text {void }} \times 0.00001\right) / S_{T}=716.3265
$$

where $S_{T}$ is the area of whole core in the $x-y$ plane and $S_{v o-}$ ${ }_{i d}$ is the area of void part.

$$
S_{T}=4 \times 0.7677 \times 0.4432=1.3611
$$




$$
S_{\text {void }}=8 \times 0.5 \times(0.2193+0.4387) \times 0.3799=0.9847
$$

Because these two honeycomb cores are identical with the volume fraction, the effective density of rectangular honeycomb core is also 716.3265. The average of the mass density across the thickness for sandwich panel is:

$$
\begin{aligned}
\rho & =\frac{1}{h} \sum_{k=1}^{N} \rho_{k}\left(h_{k}-h_{k-1}\right) \\
& =\frac{1}{0.05}(7800 \times 0.02+716.3265 \times 0.03)=3549.796
\end{aligned}
$$

According to Eq.(40), the natural frequencies of sandwich panel with the homogenized hexagonal and rectangular cores are obtained in Table 7.

Table 7. Natural frequencies with different $m$ and $n$

\begin{tabular}{cccccc}
\hline$m, n$ & $\begin{array}{c}m=1 \\
n=1\end{array}$ & $\begin{array}{c}m=1 \\
n=2\end{array}$ & $\begin{array}{c}m=1 \\
n=3\end{array}$ & $\begin{array}{c}m=2 \\
n=1\end{array}$ & $\begin{array}{c}m=2 \\
n=2\end{array}$ \\
\hline $\begin{array}{c}\text { for the } \\
\begin{array}{c}\text { hexagonal } \\
\text { core } \\
\text { for the }\end{array}\end{array}$ & 272.75 & 474.17 & 803.55 & 868.13 & 1061.99 \\
$\begin{array}{c}\text { rectangular } \\
\text { rectang }\end{array}$ & 273.55 & 474.42 & 803.88 & 873.4 & 1065.4
\end{tabular}

core

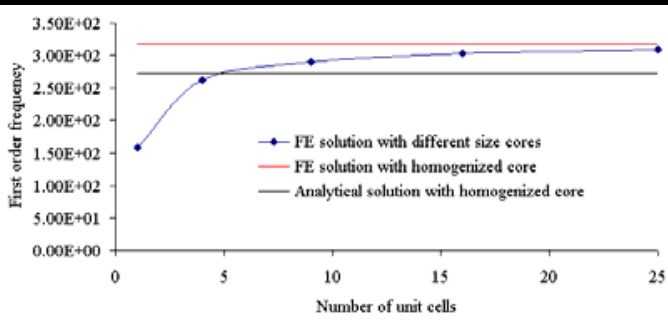

(a)

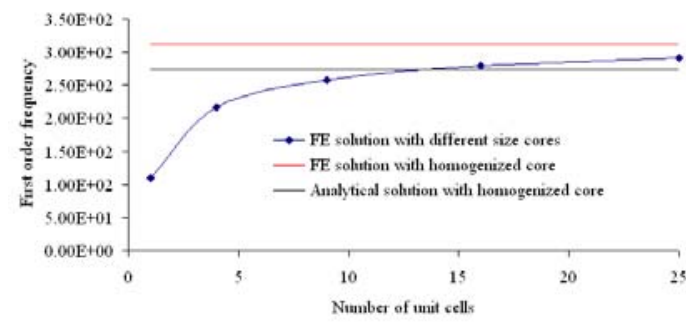

Fig.16. Frequency variation of the first order vibration with different size (a) hexagonal and (b) rectangular cores

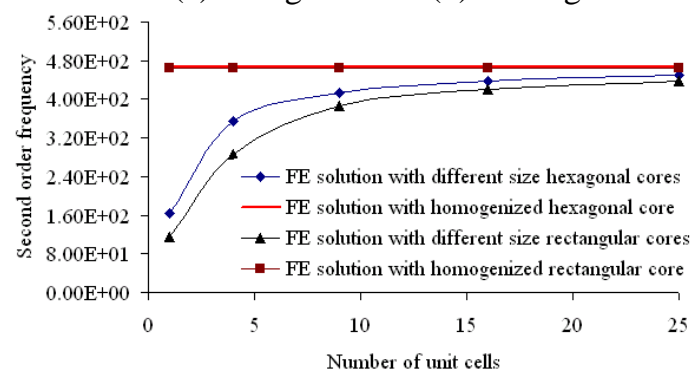

Fig.17. Frequency variation of the second order vibration with different size hexagonal and rectangular cores

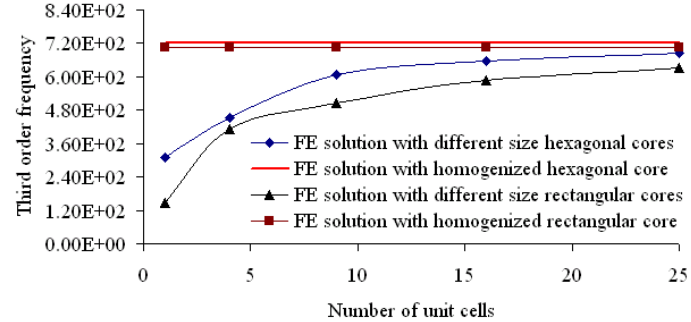

Fig.18. Frequency variation of the third order vibration with different size hexagonal and rectangular cores

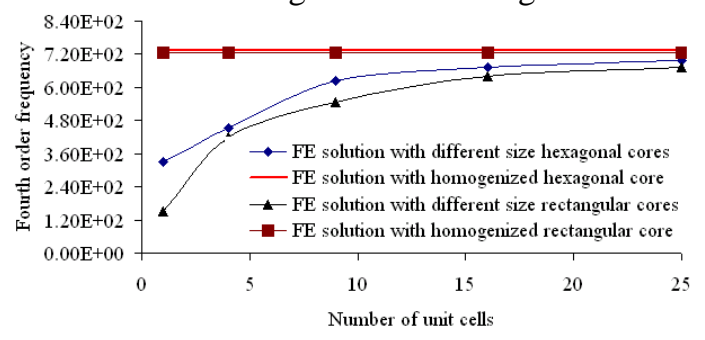

Fig.19. Frequency variation of the fourth order vibration with different size hexagonal and rectangular cores

The finite element models of sandwich panels with the different size hexagonal and rectangular cores and their homogenized cores are built and their eigen-frequencies and the five order vibration modes are calculated as shown in Table 8 to Table 12 and Fig.16 to Fig.20.

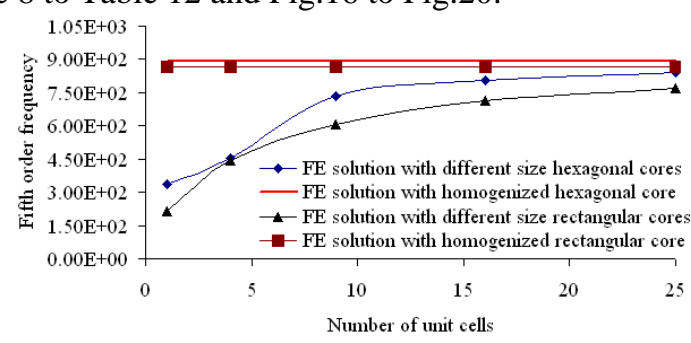

Fig.20. Frequency variation of the fifth order vibration with different size hexagonal and rectangular cores

\begin{tabular}{|c|c|c|c|c|c|}
\hline $\begin{array}{c}\text { Number } \\
\text { of unit } \\
\text { cell }\end{array}$ & $1 \times 1$ & $2 \times 2$ & $3 \times 3$ & $4 \times 4$ & $5 \times 5$ \\
\hline $\begin{array}{l}\text { Different } \\
\text { sizes } \\
\text { cores }\end{array}$ & & & 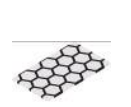 & & \\
\hline $\begin{array}{l}\text { Frequen- } \\
\text { cy }\end{array}$ & $\begin{array}{c}1.59 \mathrm{E} \\
+2\end{array}$ & $2.62 E+2$ & $2.91 \mathrm{E}+2$ & $3.03 E+2$ & $3.09 \mathrm{E}+2$ \\
\hline $\begin{array}{c}\text { Mode of } \\
\text { sandwich } \\
\text { panel }\end{array}$ & & & & & \\
\hline $\begin{array}{c}\text { Different } \\
\text { sizes } \\
\text { cores }\end{array}$ & & & & & \\
\hline $\begin{array}{l}\text { Frequen- } \\
\text { cy }\end{array}$ & $\begin{array}{c}1.10 \mathrm{E} \\
+2\end{array}$ & $2.17 \mathrm{E}+2$ & $2.57 \mathrm{E}+2$ & $2.80 \mathrm{E}+2$ & $2.92 \mathrm{E}+2$ \\
\hline
\end{tabular}

Table 8. The first order vibration response with the different size hexagonal and rectangular cores 


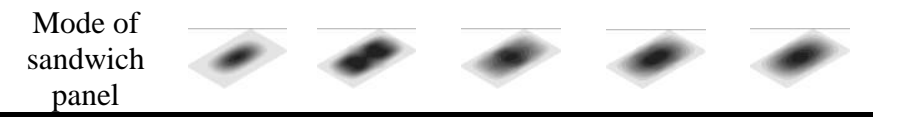

Table 9. The second order vibration response with the different size hexagonal and rectangular cores

$\begin{gathered}\text { Number } \\ \text { of unit } \\ \text { cell }\end{gathered}$
$\begin{gathered}\text { Different } \\ \text { sizes } \\ \text { cores }\end{gathered}$
$\begin{gathered}\text { Frequen- } \\ \text { cy }\end{gathered}$

Table 10. The third order vibration response with the different size hexagonal and rectangular cores

\begin{tabular}{|c|c|c|c|c|c|}
\hline $\begin{array}{c}\text { Number } \\
\text { of unit } \\
\text { cell }\end{array}$ & $1 \times 1$ & $2 \times 2$ & $3 \times 3$ & $4 \times 4$ & $5 \times 5$ \\
\hline $\begin{array}{l}\text { different } \\
\text { sizes } \\
\text { cores }\end{array}$ & & & 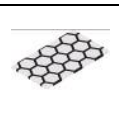 & & \\
\hline $\begin{array}{c}\text { Fre- } \\
\text { quency }\end{array}$ & $3.12 \mathrm{E}+2$ & $4.53 \mathrm{E}+2$ & $6.06 \mathrm{E}+2$ & $6.58 \mathrm{E}+2$ & $6.83 E+2$ \\
\hline $\begin{array}{l}\text { Mode of } \\
\text { sand- } \\
\text { wich } \\
\text { panel }\end{array}$ & &. & 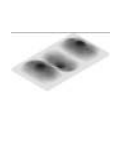 & & \\
\hline $\begin{array}{l}\text { sizes } \\
\text { cores }\end{array}$ & & & & & \\
\hline $\begin{array}{c}\text { Fre- } \\
\text { quency } \\
\text { Mode of }\end{array}$ & $1.48 \mathrm{E}+2$ & $4.14 \mathrm{E}+2$ & $5.05 E+2$ & $5.87 \mathrm{E}+2$ & $6.32 E+2$ \\
\hline $\begin{array}{l}\text { sand- } \\
\text { wich } \\
\text { panel }\end{array}$ & 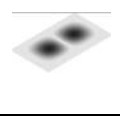 & & 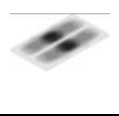 & & \\
\hline
\end{tabular}

Table 11. The fourth order vibration response with the different size hexagonal cores

\begin{tabular}{|c|c|c|c|c|c|}
\hline $\begin{array}{c}\text { Number } \\
\text { of unit } \\
\text { cell }\end{array}$ & $1 \times 1$ & $2 \times 2$ & $3 \times 3$ & $4 \times 4$ & $5 \times 5$ \\
\hline $\begin{array}{l}\text { different } \\
\text { sizes } \\
\text { cores }\end{array}$ & & & 8 & & \\
\hline $\begin{array}{c}\text { Fre- } \\
\text { quency }\end{array}$ & $3.30 \mathrm{E}+2$ & $4.53 \mathrm{E}+2$ & $6.25 E+2$ & $6.74 \mathrm{E}+2$ & $6.99 \mathrm{E}+2$ \\
\hline $\begin{array}{l}\text { Mode of } \\
\text { sand- }\end{array}$ & & & $\%$ & & \\
\hline
\end{tabular}

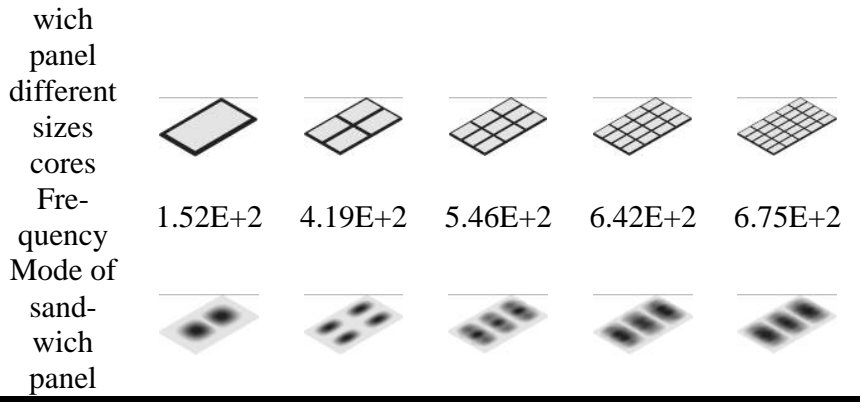

Table 12. The fifth order vibration response with the different size hexagonal and rectangular cores

\begin{tabular}{|c|c|c|c|c|c|}
\hline $\begin{array}{c}\text { Number } \\
\text { of unit } \\
\text { cell }\end{array}$ & $1 \times 1$ & $2 \times 2$ & $3 \times 3$ & $4 \times 4$ & $5 \times 5$ \\
\hline $\begin{array}{c}\text { different } \\
\text { sizes } \\
\text { cores }\end{array}$ & & 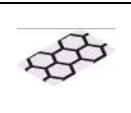 & 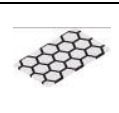 & & \\
\hline $\begin{array}{c}\text { Fre- } \\
\text { quency } \\
\text { Mode of }\end{array}$ & $3.38 \mathrm{E}+2$ & $4.53 E+2$ & $7.34 \mathrm{E}+2$ & $8.06 \mathrm{E}+2$ & $8.42 \mathrm{E}+2$ \\
\hline $\begin{array}{l}\text { sand- } \\
\text { wich } \\
\text { panel }\end{array}$ & & & & & \\
\hline $\begin{array}{l}\text { sizes } \\
\text { cores }\end{array}$ & & & & & \\
\hline $\begin{array}{c}\text { Fre- } \\
\text { quency } \\
\text { Mode of }\end{array}$ & $2.15 E+2$ & $4.42 \mathrm{E}+2$ & $6.07 \mathrm{E}+2$ & $7.13 \mathrm{E}+2$ & $7.70 \mathrm{E}+2$ \\
\hline $\begin{array}{l}\text { sand- } \\
\text { wich } \\
\text { panel }\end{array}$ & $\rightarrow$ & & & & \\
\hline
\end{tabular}

\subsection{Sandwich panel with square and rhombic honeycomb cores}

Consider a sandwich panel with the square and rhombic honeycomb core as shown in Fig.7. All the four edges are simply supported. The dimensions of the sandwich panel are assigned as: $\mathrm{a}=1.1 \mathrm{~m}, \mathrm{~h}_{\mathrm{u}}=\mathrm{h}_{\mathrm{l}}=0.01 \mathrm{~m}, \mathrm{~h}_{\mathrm{c}}=0.03 \mathrm{~m}$ (u-upper skin, l-lower skin, and c-core). Similar to the hexagonal core in the section 6.2.1, the elastic moduli of the upper and lower skins are $210 \mathrm{GPa}$. The density is $7800 \mathrm{~kg} / \mathrm{m} 3$. For the core, the elastic modulus is $75 \mathrm{GPa}$ and the density is $2700 \mathrm{~kg} / \mathrm{m}^{3}$ (solid or black part). In the same way, we assume that the void or white part is a very weak material: the elastic modulus is $0.00001 \mathrm{GPa}$ and density is $0.00001 \mathrm{~kg} / \mathrm{m}^{3}$.

With the 3D homogenization method, the effective material properties of square honeycomb core are

$$
\begin{aligned}
& E_{x}^{H}=7.227631 \mathrm{E}+09, E_{y}^{H}=7.227631 \mathrm{E}+09, E_{z}^{H}=1.301653 \mathrm{E}+10 \\
& G_{x y}^{H}=3.424314 \mathrm{E}+07, G_{y z}^{H}=2.695173 \mathrm{E}+09, G_{x z}^{H}=2.695173 \mathrm{E}+09 \\
& v_{x y}^{H}=-6.337963 \mathrm{E}-03, v_{x z}^{H}=1.665797 \mathrm{E}-01, v_{y z}^{H}=1.665797 \mathrm{E}-01
\end{aligned}
$$

The effective material properties of rhombic honeycomb core are 
$E_{x}^{H}=1.766130 \mathrm{E}+08, E_{y}^{H}=1.771721 \mathrm{E}+08, E_{z}^{H}=1.301653 \mathrm{E}+10$

$G_{x y}^{H}=3.671618 \mathrm{E}+09, G_{y z}^{H}=2.723917 \mathrm{E}+09, G_{x z}^{H}=2.715759 \mathrm{E}+09$

$v_{x y}^{H}=9.740973 \mathrm{E}-01, v_{x z}^{H}=4.070510 \mathrm{E}-03, v_{y z}^{H}=4.083396 \mathrm{E}-03$

And the effective density of two honeycomb cores is same and computed as following,

$$
\rho_{c}=\left(\left(1.1^{2}-1^{2}\right) * 2700+1^{2} * 0.00001 / 1.12=468.595\right.
$$

The average of the mass density across the thickness for sandwich panel:

$$
\begin{aligned}
\rho & =\frac{1}{h} \sum_{k=1}^{N} \rho_{k}\left(h_{k}-h_{k-1}\right) \\
& =\frac{1}{0.05}(7800 \times 0.02+468.595 \times 0.03)=3401.157
\end{aligned}
$$

According to Eq.(40), the natural frequencies of sandwich panel with the homogenized square and rhombic cores are obtained in Table 13.
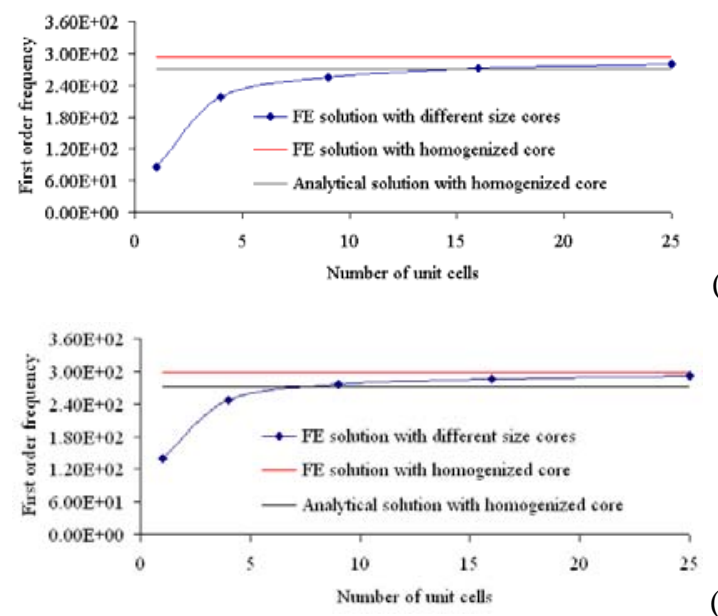

Fig.21. Frequency variation of the first order vibration with different size (a) square and (b) rhombic cores

Table 13. Natural frequencies with different values of m

\begin{tabular}{cccccc}
\multicolumn{7}{c}{ and $n$} \\
\hline$m, n$ & $\begin{array}{c}m=1 \\
n=1\end{array}$ & $\begin{array}{c}m=1 \\
n=2\end{array}$ & $\begin{array}{c}m=1 \\
n=3\end{array}$ & $\begin{array}{c}m=2 \\
n=1\end{array}$ & $\begin{array}{c}m=2 \\
n=2\end{array}$ \\
\hline $\begin{array}{c}\text { for the } \\
\text { square } \\
\text { core } \\
\text { for the } \\
\text { rhombic } \\
\text { core }\end{array}$ & 271.29 & 669.17 & 1308.9 & 669.17 & 1055.2 \\
\hline
\end{tabular}

The finite element models of sandwich panels with the different size square and rhombic cores and the homogenized cores are built and their five order eigen-frequencies and vibration modes are calculated as shown in Table 14 to Table 18 and Fig.21 to Fig.25.

\begin{tabular}{|c|c|c|c|c|c|}
\hline $\begin{array}{c}\text { Number } \\
\text { of unit } \\
\text { cell }\end{array}$ & $1 \times 1$ & $2 \times 2$ & $3 \times 3$ & $4 \times 4$ & $5 \times 5$ \\
\hline $\begin{array}{l}\text { different } \\
\text { sizes } \\
\text { cores }\end{array}$ & & & & & \\
\hline $\begin{array}{c}\text { Fre- } \\
\text { quency } \\
\text { Mode of }\end{array}$ & $8.62 \mathrm{E}+1$ & $2.18 \mathrm{E}+2$ & $2.55 \mathrm{E}+2$ & $2.72 \mathrm{E}+2$ & $2.81 \mathrm{E}+2$ \\
\hline $\begin{array}{l}\text { sand- } \\
\text { wich } \\
\text { panel }\end{array}$ & & & & & \\
\hline $\begin{array}{l}\text { sizes } \\
\text { cores }\end{array}$ & & $\square$ & \# & 曲 & 曲聿 \\
\hline $\begin{array}{c}\text { Fre- } \\
\text { quency } \\
\text { Mode of }\end{array}$ & $1.41 \mathrm{E}+2$ & $2.47 \mathrm{E}+2$ & $2.77 \mathrm{E}+2$ & $2.86 \mathrm{E}+2$ & $2.91 \mathrm{E}+2$ \\
\hline $\begin{array}{l}\text { sand- } \\
\text { wich } \\
\text { panel }\end{array}$ & & & & & \\
\hline
\end{tabular}

Table 14. The first order vibration response with the different size square and rhombic cores

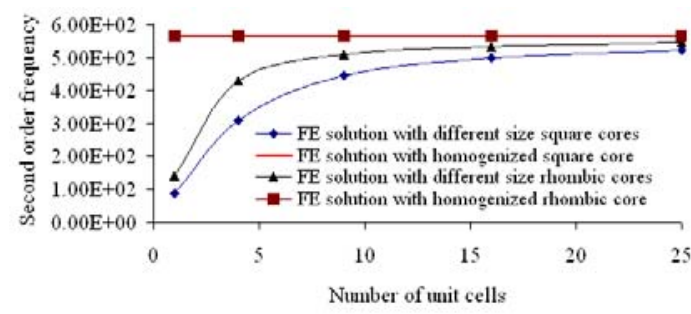

Fig.22. Frequency variation of the second order vibration with different size square and rhombic cores

Table 15. The second order vibration response with the different size square and rhombic cores

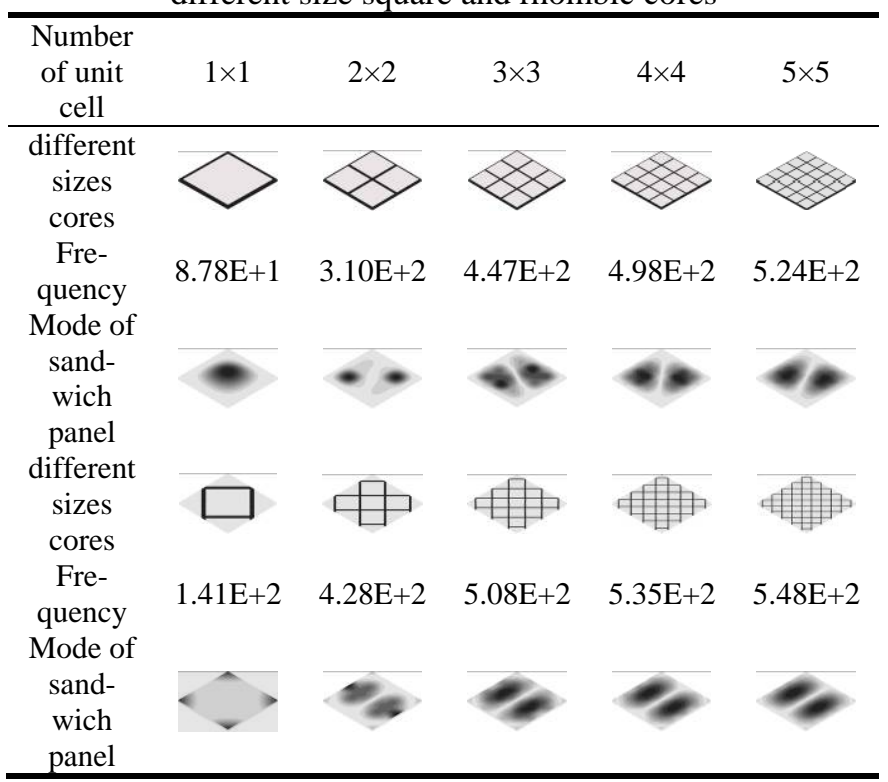

Table 16. The third order vibration response with the different size square and rhombic cores

\begin{tabular}{llllll}
\hline $\begin{array}{c}\text { Number } \\
\text { of unit } \\
\text { cell }\end{array}$ & $1 \times 1$ & $2 \times 2$ & $3 \times 3$ & $4 \times 4$ & $5 \times 5$ \\
\hline $\begin{array}{c}\text { different } \\
\text { sizes }\end{array}$ & $>$ & 8 & 8 & 8 & 8
\end{tabular}


K.P. Qiu et al.: Bending and dynamic analyses of sandwich panels
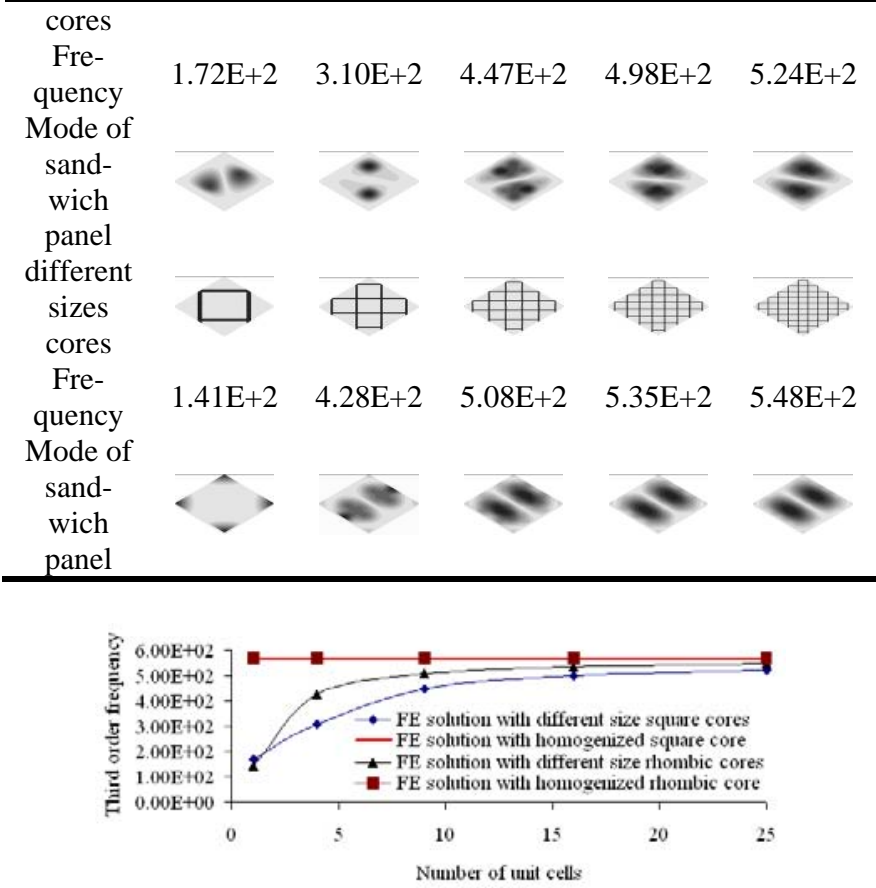

Fig.23. Frequency variation of the third order vibration with different size square and rhombic cores

\subsection{Discussion}

From Tables 6-10, Tables 12-16 and Figs.16-25, it is also demonstrated that the vibration frequencies and modes of sandwich panel approach the limit values with the homogenized cores with increasing the number of unit cells or decreasing the size of unit cells. Actually, these cases are reasonable. We can imagine that the material distributions are more and more homogeneous with the increasing number of unit cells under the same material amount and configurations of unit cells. Therefore the performance of sandwich panels for the free vibration is improved.

Table 17. The fourth order vibration response with the different size square and rhombic cores

$\begin{gathered}\text { Number } \\ \text { of unit } \\ \text { cell }\end{gathered}$
$\begin{gathered}\text { different } \\ \text { sizes } \\ \text { cores } \\ \text { Fre- } \\ \text { quency } \\ \text { Mode of } \\ \text { sand- } \\ \text { wich } \\ \text { panel } \\ \text { different } \\ \text { sizes } \\ \text { cores } \\ \begin{array}{c}\text { Fre- } \\ \text { quency } \\ \text { Mode of } \\ \text { sand- } \\ \text { wich } \\ \text { panel }\end{array}\end{gathered}$

Table 18. The fifth order vibration response with the different size square and rhombic cores

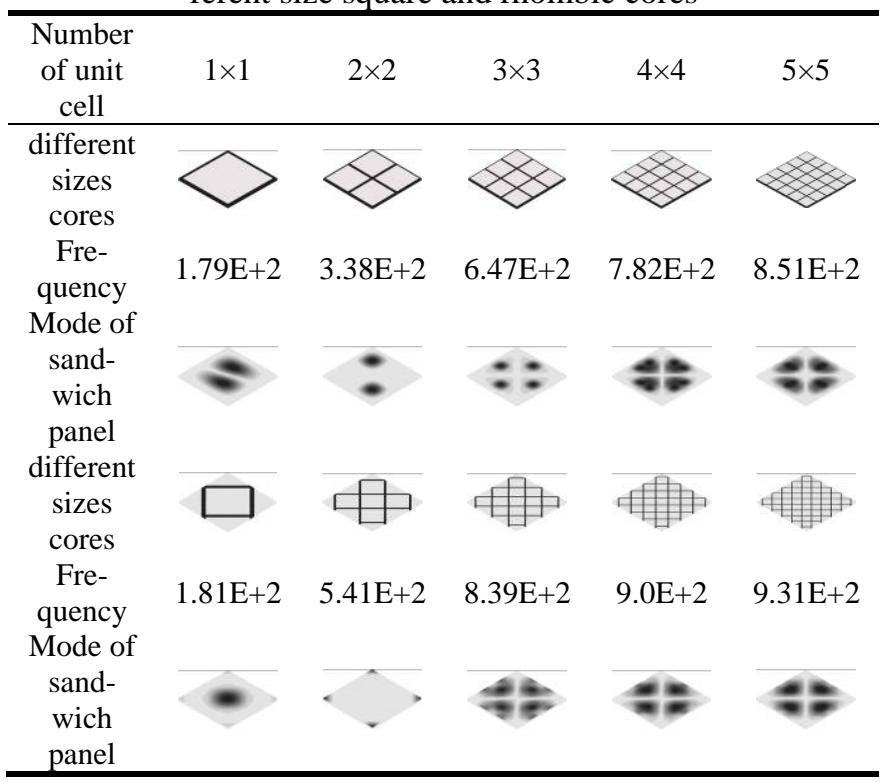

In addition, the natural frequencies of sandwich panels are obtained with the laminated plate theory including the transverse shear deformation on the basis of the homogenized cores. The fundamental frequency occurs with $m=n=1$, which is for one half sine wave in each direction. Natural frequencies for the two sandwich panels are listed in Table 7 and Table 13 with the different $m$ and $n$. Variation of $m$ has greater influence on natural frequencies than $\mathrm{n}$ for sandwich panel with the hexagonal and rectangular cores because $\mathrm{m}$ is the number of $\mathrm{x}$ axial half-waves corresponding to the short side. Variation of $\mathrm{m}$ and $\mathrm{n}$ has the same influence on natural frequencies for sandwich panel with the square and rhombic cores. By observing the Fig.16 and Fig.21, the deviation between the analytical solution and the FE solution with homogenized square and rhombic cores is less than with homogenized hexagonal and rectangular cores. Similar to section 3.1, the ratio of the span dimensions to thickness ( $\alpha=a / h$ ) is 17.73 for the hexagonal and rectangular cores which is less than for the square and rhombic cores ( $\alpha=22$ ). Therefore, the laminated plate theory for dynamic analysis is also more applicable to the thin plate.

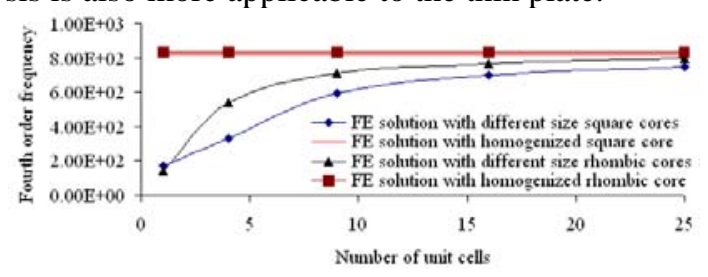

Fig.24. Frequency variation of the fourth order vibration with different size square and rhombic cores

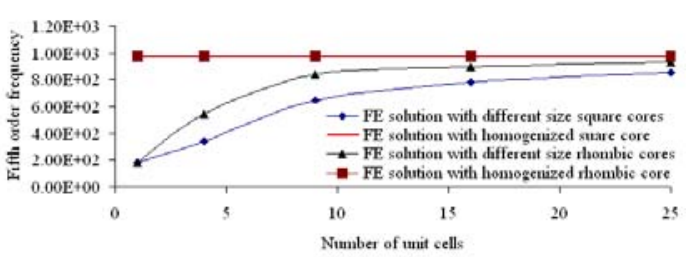


Fig.25. Frequency variation of the fifth order vibration with different size square and rhombic cores

And also we compare the dynamic response of sandwich panels with the different configuration of sandwich cores and with the same volume fraction. The FE analysis results show that the natural frequencies of sandwich panels with the hexagonal cores are bigger than the rectangular cores. And the natural frequencies of sandwich panels with the square cores are smaller than the rhombic cores. However their natural frequencies obtained by the analytical method are very close.

\section{Conclusions and further works}

In this paper, we analyzed the bending and dynamic responses of sandwich panels with the size variation of the different cores. Conclusions can be drawn as follows: (1) with decreasing the size of unit cells, the deformation and natural frequency of the sandwich panel with different size cores tends to the one with homogenized cores. So the homogenization method is valid in analyzing the sandwich panel when the number of core unit cells is many enough; (2) it is verified that the laminate plate theory is adapted to the static and dynamic analysis for sandwich panel with the homogenized sandwich core when the ratio $\alpha$ of span dimensions to thickness of sandwich panel satisfies the requirement of the lamination theory; (3) the size effect of cores is very obvious and important for the structural response of sandwich panels. Special attention must be paid when the core number is small; (4) the more suitable configuration of unit cells in sandwich cores can be chose under the given boundary condition and the analysis of structural responses.

The above examples also show that the Navier solution of sandwich panels with the square and rhombic cores and the analytical solution of dynamic responses are very close. The influence of configuration of sandwich cores on the structural response of sandwich panels cannot be reflected by using the classical laminate plate theory. Therefore, in further works, the high order laminate plate theory needs to be adopted in order to improve the analytical accuracy for sandwich panel with the homogenized cores. Besides, the influence of size effect on buckling and thermal responses of sandwich structures can be further studied. And the new configurations of sandwich cores that possess extraordinary properties are designed considering the integrated performances of sandwich panels by the multi-objective optimization.

\section{References}

1. L.J. Gibson, M.F. Ashby, Cellular solids structure and properties (Oxford, Pergamon Press, 1998).

2. N. Wicks, J.W. Hutchinson, Performance of sandwich plates with truss cores. Mechanics of Materials, 36, 739751 (2004).

3. A. Petras, M.P.F. Sutcliffe, Failure mode maps for honeycomb sandwich panels. Composite Structures. 44, 237-252 (1999).

4. L. Valdevit, Z. Wei, C. Mercer, F.W. Zok, A.G. Evans, Structural performance of near-optimal sandwich panels with corrugated cores. International Journal of Solids and Structures, 43, 4888-4905 (2006).

5. D. Lukkassen, A. Meidell, Advanced Materials and Structures and their Fabrication Processes. Third edition, (Narvik University College, HiN, 2003).

6. H. Zhu, B.V. Sankar, Analysis of sandwich TPS panel with functionally graded foam core by Galerkin method. Composite Structures, 77, 280-287 (2007).

7. M. Styles, P. Compston, S. Kalyanasundaram, The effect of core thickness on the flexural behaviour of aluminiumfoam sandwich structures. Composite Structures, 80, 532-538 (2007).

8. N. Buannic, P. Cartraud, T. Quesnel, Homogenization of corrugated core sandwich panels. Composite Structures, 59, 299-312 (2003).

9. F. Meraghni, F. Desrumaux, M.L. Benzeggagh, Mechanical behavior of cellular core for structural sandwich panels. Composites, Part A, 30, 767-779 (1999).

10. X. F. Xu, P. Qiao, Homogenized elastic properties of honeycomb sandwich with skin effect. International Journal of Solids and Structures, 39, 2153-2188 (2002).

11. J. Hohe, W. Becker, An energetic homogenization procedure for the elastic properties of general cellular sandwich cores. Composites, Part B, 32, 185-197 (2001).

12. Z. Xue, J.W. Hutchinson, Constitutive model for quasistatic deformation of metallic sandwich cores. International Journal for Numerical Methods in Engineering, 61, 2205-2238 (2004).

13. J. Romanoff, P. Varsta, Bending response of web-core sandwich plates. Composite Structures, 81, 292-302 (2007).

14. C.E. Glenn, M.W. Hyer, Bending behavior of low-cost sandwich plates, Composites, Part A, 36, 1449-1465 (2005).

15. J.K. Paik, A.K. Thayamballi, G.S. Kim, The strength characteristics of aluminum honeycomb sandwich panels. Thin-Walled Structures, 35, 205-231 (1999).

16. V. Koissin, V. Skvortsov, S. Krahmalev, A. Shilpsha, The elastic response of sandwich structures to local loading. Composite Structures 63, 375-385 (2004).

17. M. Meo, R. Vignjevic, G. Marengo, The response of honeycomb sandwich panels under low-velocity impact loading. International Journal of Mechanical Sciences, 47, 1301-1325 (2005).

18. N. Pokharel, M. Mahendran, Finite element analysis and design of sandwich panels subject to local buckling effects. Thin-Walled Structures, 42, 589-611 (2004).

19. Y. Frostig, O.T. Thomsen, High-order free vibration of sandwich panels with a flexible core. International Journal of Solids and Structures, 41, 1697-1724 (2004).

20. W.S. Chang, E. Ventsel, T. Krauthammer, J. John, Bending behavior of corrugated-core sandwich plates. Composite Structures, 70, 81-89 (2005).

21. C. Tekoglu, P.R. Onck, Size effects in the mechanical behavior of cellular materials. Journal of Materials Science, 40, 5911-5917 (2005).

22. P.R. Onck, E.W. Andrews, L.J. Gibson, Size effects in ductile cellular solids. Part I, modeling. International Journal of Mechanical Sciences, 43, 681-699 (2001).

23. G.M. Dai, W.H. Zhang, Size effects of basic cell in static analysis of sandwich beams. International Journal of Solids and Structures, 45, 2512-2533 (2008). 
24. B. Hassani, E. Hinton, A review of homogenization and topology and topology optimization I-homogenization theory for media with periodic structure. Computers \& Structures, 69, 707-717 (1998).

25. B. Hassani, E. Hinton, A review of homogenization and topology and topology optimization II-analytical and numerical solution of homogenization equations. Computers \& Structures, 69, 719-738 (1998).

26. J.R. Vinson, R.L. Sierakowski, The behavior of structure composed of composite materials. (Martinus Nijhoff Publishers, 1987).

27. J.N. Reddy, Energy and variational methods in applied mechanics. (Wiley-Interscience publication, 1984). 